\title{
LOS SEPULCROS TURRIFORMES DE DAIMUZ Y VILLAJOYOSA: DOS MONUMENTOS ROMANOS OLVIDADOS *
}

\author{
LORENZO ABAD CASAL \\ Universidad de Alicante \\ MANUEL BENDALA GALÁN \\ Universidad Autónoma de Madrid
}

\begin{abstract}
Se estudian dos monumentos turriformes romanos de considerable sencillez y gran semejanza tipológica; uno desaparecido, que se conoce a través de dibujos antiguos (Daimuz, Valencia), y otro relativamente bien conservado en la actualidad (Villajoyosa, Alicante). A mbos pueden datarse a mediados del siglo II d.C. y se inscriben en la amplia serie de sepulcros de este tipo existentes a lo largo del Imperio, mostrando relaciones con algunos centroeuropeos y, sobre todo el de Villajoyosa, con los del norte de Africa.

This paper deals with two very simple and similar Roman funerary towers, one disappeared, but known by ancient drawings, at Daimuz (Valencia), and another relatively well preserved at Villajoyosa (Alicante). Both monuments are dated about the middle of II c. A. D., and inscribed in the group of funerary towers in the Roman Empire. They are similar to some monuments of Central Europe and - principally the one at Viliajoyosa - to some of North África.
\end{abstract}

Entre los monumentos romanos del País Valenciano se cuentan dos edificios funerarios (figs. $1 \mathrm{y}$ 2) que, pese a su importancia, apenas han atraído hasta el momento la atención de los investigadores: las torres de Daimuz (destruida a comienzos del siglo $\mathrm{XX}$ ) y de Villajoyosa (conservada actualmente en sus dos terceras partes). Tan sólo han merecido unas líneas en los estudios sobre este tipo de monu-

(*) Este trabajo se inscribe dentro del programa de investigación que sobre diversos aspectos del poblamiento prehistórico y antiguo de la provincia de Alicante está realizando, bajo los auspicios de la CAICYT, el Departamento de Prehistoria y Arqueología de la Universidad de Alicante. Su elaboración se ha visto considerablemente facilitada por la estancia de uno de los autores (L. A.) en la sede berlinesa del Deutsches Archäologisches Institut, gracias a una invitación de este organismo, y por la colaboración que en todo momento hemos encontrado en D. Manuel Arteseros, actual propietario del monumento. mentos realizados en los últimos decenios, y para su conocimiento hay que recurrir aún a los dibujos del Conde de Lumiares, del siglo XVIII, y de A. de Laborde, de comienzos del XIX. Es nuestra intención en este artículo darlos a conocer a la comunidad científica y realizar el estudio de sus características principales y del lugar que les corresponde en el ámbito funerario romano.

\section{LA TORRE DE DAIMUZ}

\subsection{Historia de la investigación}

Para los valencianos de siglos pasados, el monumento debía ser poco conocido, ya que un autor como A. de Valcárcel, que tanto se preocupó de las antigüedades valencianas, tan sólo indica que «en la torre de la casa del señor del pueblo», sin referir- 
se para nada a su antigüedad, «se encuentra una inscripción» (VALCÁRCEL, sf, 32), y las citas que de él hace Ceán Bermúdez están más relacionadas con la aparición en sus proximidades de un depósito de huesos y esculturas que con el propio edificio (CEÁN BERMÚDEZ, 1832, 37, 50; ABAD, 1985, 363). El único autor que modernamente se ha ocupado de ella, F. Pons, la pone en relación con la vía romana que desde Sucrone se dirigía a Dianium, y con la necrópolis romana existente bajo un grupo escolar próximo (PONS, 1973, sp; LLOBREGAT, 1983, 225 ss.).

La descripción más exacta que de ella poseemos es la que realizó a comienzos del siglo XIX el céle-

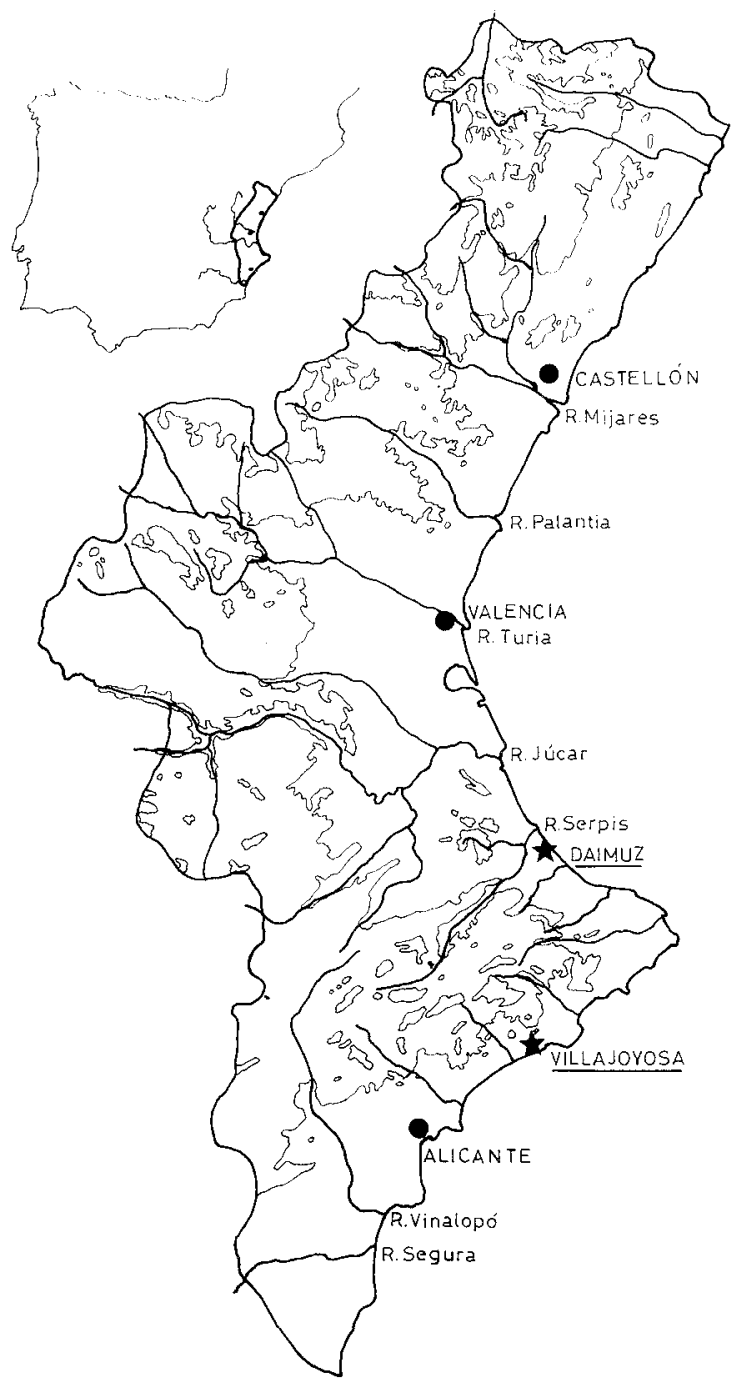

Fig. 1.--Mapas de la Península Ibérica y de la Comunidad Valenciana con la ubicación de los monumentos. bre viajero francés $\mathrm{A}$. de Laborde, que está acompañada por ilustraciones (figs. 3, 4 y 5) comentadas del mayor interés. Su descripción dice así:

«(...) C'est un monument sépulcral de construction romaine, d'une belle exécution, et donc la partie inférieure sert de base à une tour bâtie tout récemment.

L'édifice est carré, et comporte différentes dimensions, suivant les différents ordres d'assises dont il est composé. La côte du carré a 29 palmes de largeur dans les fondations, 25 à la base, et 20 au corps de l'édifice. Deux pilastres de l'ordre corinthien en décorent chaque angle, et le stylobate sur lequel posent ces pilastres est d'un assez beau caractere. Les corps du bâtiment est masqué en quelques endroits par des murs adjacents; mais la face du midi, représentée planche CXXVI, se découvre en entier. On y voit les restes d'une niche décorée de deux pilastres du même ordre que ceux qui son aux angles du monument. Au-dessous de la niche on lit cette inscription:

\section{BEBIAE QVIETAE EX TESTAMENTO SUO}

Sur la face représentée planche CXXVII, la colonne corinthienne est conservée dans toute sa hauteur, et couronnée de son chapiteau, qui est d'un fort bon style. C'est par cette face que l'on peut jugér de toutes les proportions de l'édifice, et du soin avec lequel il avoit été construit. Les pierres disposées en bossage peu salliant et artistement travaillé font un effet très agréable.

La porte de l'église se trouve sur cette face, et a le caractere moderne. Entré dans l'intérieur, on voit una banquette en pierre qui regne tout à l'entour de la chambre sépulcrale. La voûte est en bon état, et construite en belles pierres de taille, comme tout le reste. Ce bâtiment, qui appartient au seigneur du lieu, a bien dégénéré de sa première destination, puisqu'il sert de prison aux malfaiteurs de village: mais c'est encore un hommage rendu à la solidité des constructions romaines» (LABORDE, 1806, 48).

Más adelante, al describir su lámina CXXVIII, proseguirá de la siguiente forma:

«A. Face principale. La niche, décorée de deux pilastres, est masquée par un mur moderne: les profils des bases son très altérés. On ne peut déterminer si cette niche étoit carrée ou cintrée; il est présumable qu'elle avoit servi d'entrée pour placer le sarcophage dans l'intérieur. 


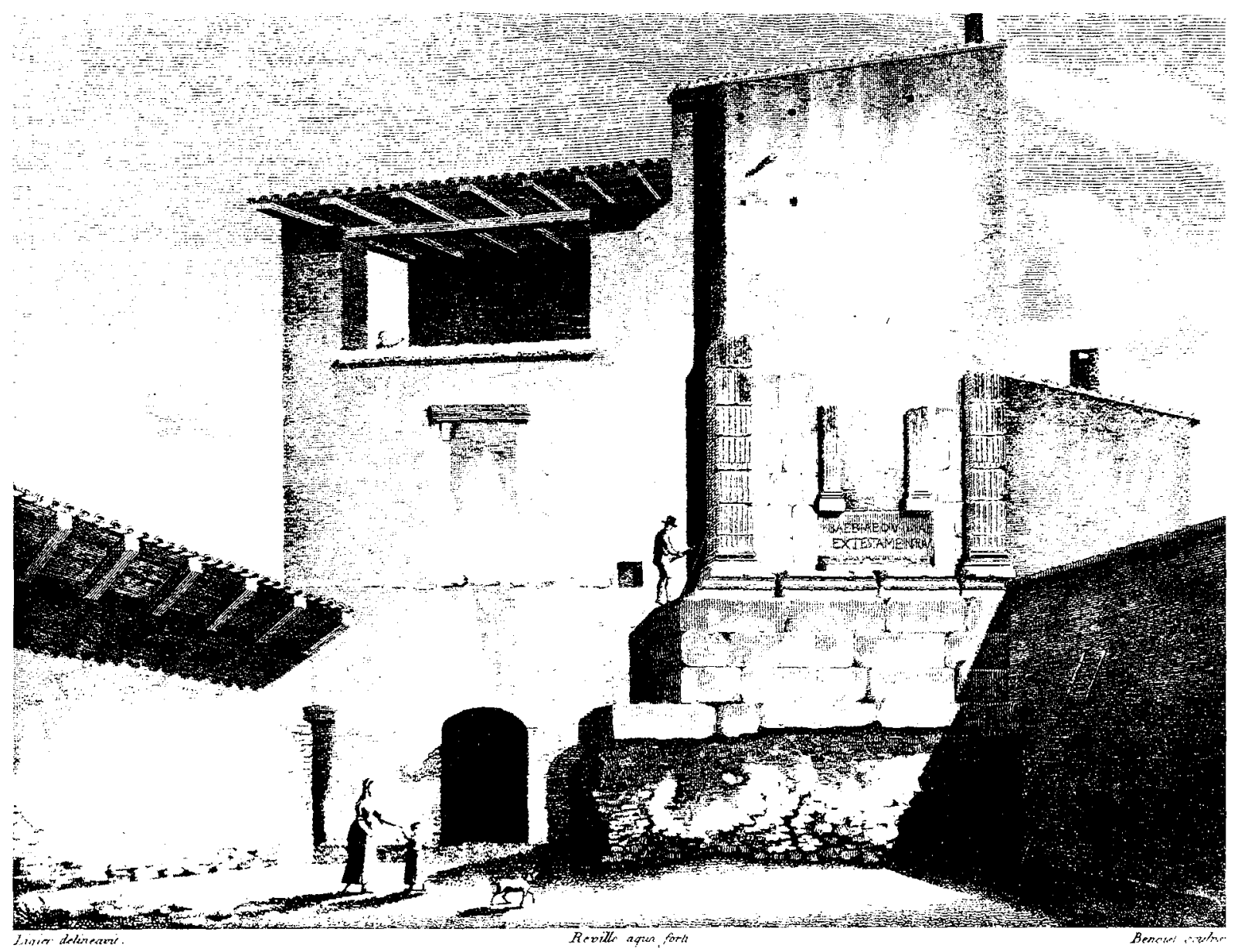

Fig. 3.-Fachada principal del monumento de Daimuz, según Laborde.

B. Face où l'on ne voit qu'un pilastre, celui qui est à gauche du dessin se trouvant aujourd'hui engagé dans un mur. La porte ne paroît point avoir entré dans la construction originaire de l'édifice: il est probable qu'elle a été pratiquée dans des temps postérieurs, lorsque le monument a changé de destination.

C. Coupe verticale du monument.

D. Plan géométral du mème» (LABORDE, 1806, 48).

\subsection{Descripción}

Los grabados de Laborde ilustran con bastante detalle la estructura de la torre y su decoración arquitectónica. La base está formada por una amplia plataforma de sillares - se observa una hilada en la fachada principal y dos en la trasera- asentada en un potente cimiento de hormigón; sobre ella, un podio prismático de tres hiladas de sillares rematado en una moldura de cyma recta éntre filetes, marca el tránsito al cuerpo central del monumento, que es de planta rectangular casi cuadrada. Tiene éste en las esquinas pilastras corintias de fuste acanalado con contraestrías en su tercio inferior (1);

(1) Un fragmento de una de estas pilastras se ha recuperado recientemente en las proximidades del monumento, y se conserva en el Museo Arqueológico de Gandia (fig. 8). Se observan aún dos estrías de sección casi semicircular y parte de una tercera en una de sus caras, y trazas de otras similares en una de las caras adyacentes; parece, por tanto, que nos encontramos ante parte de una de las pilastras de esquinas del monumento. Esta pieza, cuyo conocimiento debemos al director del Museo Arqueológico de Gandía, Joan Cardona, viene a sumarse a los si- 


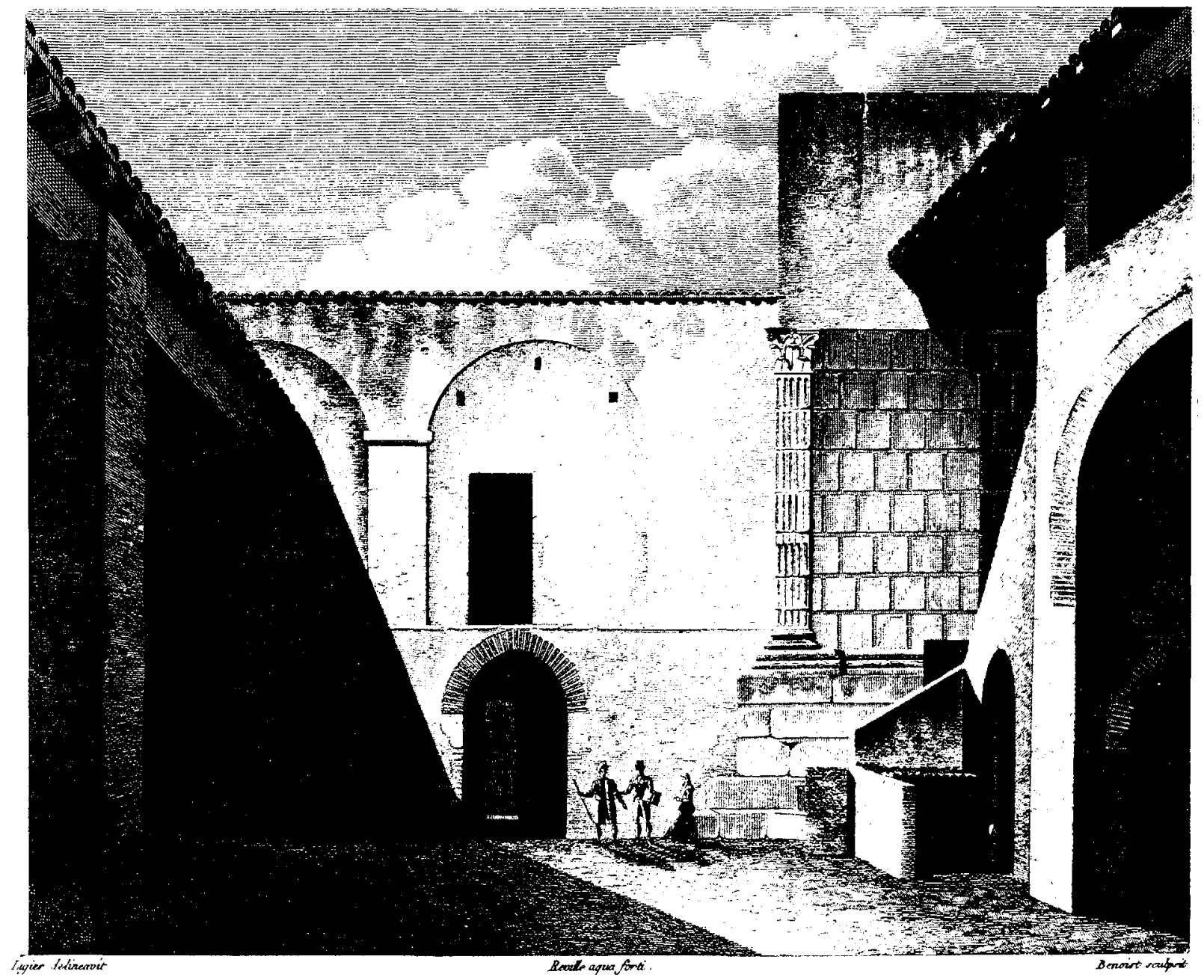

Fig. 4.-Fachada trasera del monumento de Daimuz, según Laborde.

las basas responden al tipo ático, caracterizado por dos toros entre filetes separados por una escocia, y en todos los dibujos carecen de plinto, a excepción del de la lámina CXXVII, menos técnico, en el que se ofrece una vista del estado general de la torre en

llares ya conocidos reutilizados en las casas próximas al emplazamiento de la torre, en Daimuz, y que pudimos visitar gracias a Françesc Pons. Las dimensiones de estos sillares, que oscilan entre 1 y $1,30 \mathrm{~m}$. de largo, 0,60 y $0,70 \mathrm{~m}$. de altura y unos $0,65 \mathrm{~m}$. de profundidad, vienen a coincidir con las de los sillares de Villajoyosa y confirman la semejanza de ambos monumentos. Las dimensiones del fragmento de pilastra, $0,47 \times 0,25 \times 0,21 \mathrm{~m}$., son poco significativas, ya que se encuentra incompleto en todas sus caras, pero no obstante pueden adecuarse a las de los demás sillares. Todos ellos son de piedra caliza de color gris claro tirando a pardusco. También el fragmento de inscripción de que más adelante hablaremos es de la misma piedra. medio de las construcciones modernas que se le añadieron. Los capiteles, a juzgar sobre todo por el detalle de la lámina CXXVIII, son del tipo corintio canónico y presentan esculpidos los menudos detalles de su característica ornamentación, aunque no hay que olvidar que, en ocasiones, los dibujos de Laborde pueden pecar de una idealización excesiva. Nada se conserva del entablamento.

La que debió ser fachada principal presenta, en el centro, dos pilastras de módulo menor que el de las de esquina, apeadas en una especie de podio ocupado por la leyenda Baebiae Quietae / ex testamento suo, que nos documenta a quién estaba dedicado el monumento. Por debajo de esta especie de podio simulado corre una sencilla moldura, compuesta de un filete y dos estrías unidas en arista, que reposa, a su vez, sobre la que corona el 

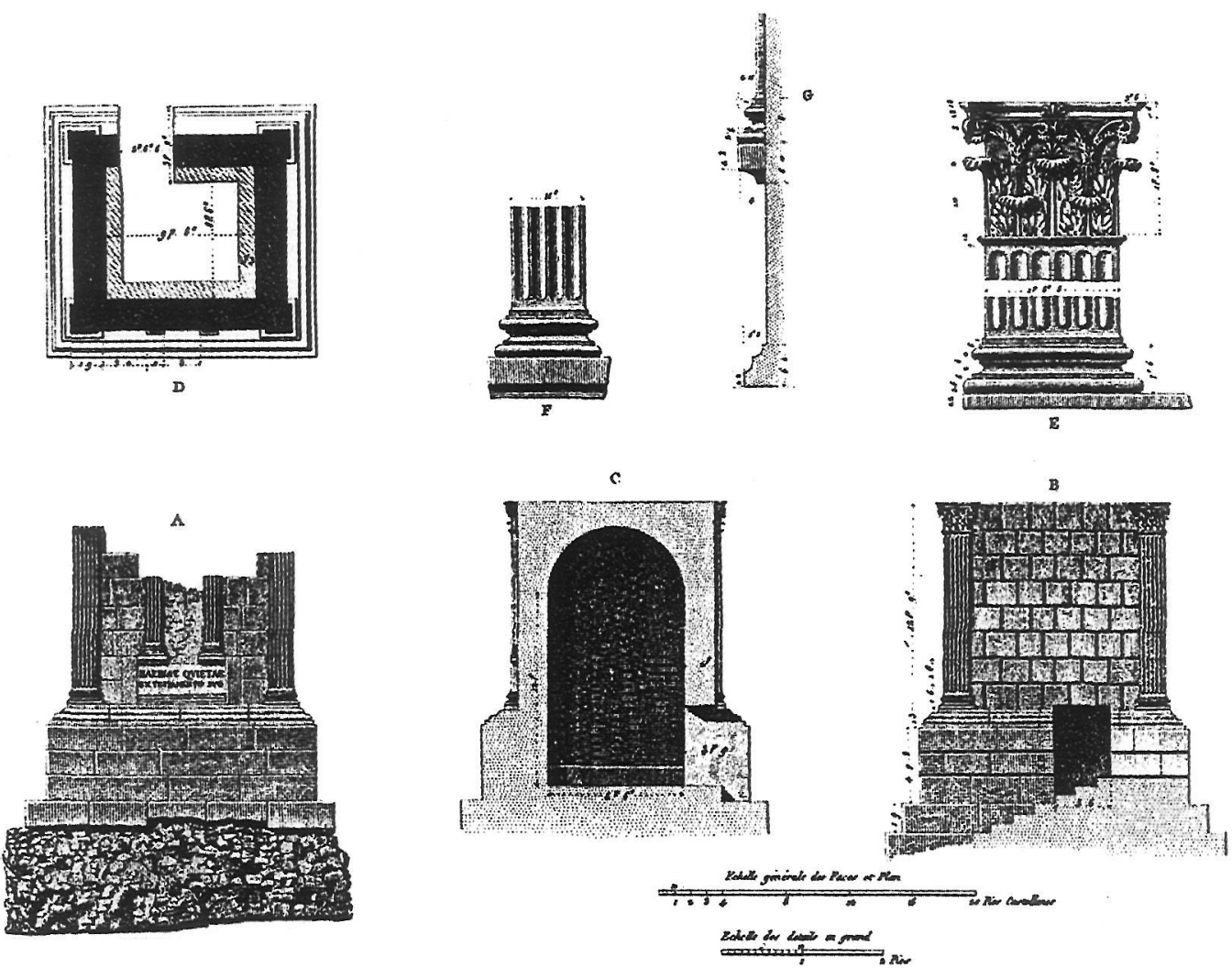

Fig. 5.-Detalles del monumento de Daimuz, según Laborde.

cuerpo inferior de la torre. Las basas de estas pilastras centrales parecen llevar, en el dibujo de Laborde, gruesos plintos, asentados sobre mensulillas de perfil cóncavo. La parte superior de las pilastras se había perdido ya en tiempos de Laborde, y es de suponer que sustentaran un arco o un entablamento, quizás con frontón, para determinar una suerte de nicho o de edícula, como conocemos en muchos otros monumentos. En su interior pudo alojarse alguna representación figurada, aunque la documentación disponible no permite decir nada seguro sobre el particular; en cualquier caso, dada la escasa profundidad del nicho, ésta debió ser pintada o relivaria, a la manera de la de la Torre de los Escipiones (2).

La fachada mayor opuesta a la principal se conservaba hasta la altura de los capiteles, con ocho hiladas de sillares en el cuerpo principal de la torre. En el podio, desplazada del centro, se abrió modernamente una amplia puerta para aprovechar la cámara interior. Se cubría ésta con bóveda de cañón, construida, según Laborde, de buena sillería y con la calidad arquitectónica de que se hizo gala en todo el monumento (3).

\subsection{La inscripción}

Diversos autores han reproducido la inscripción del monumento. El cronista Pere Antón Beuter la leyó como Baebiae Qui --- eae / ex testamen-

(2) No obstante, a juzgar por el corte irregular del lado derecho del plinto en el dibujo de detalle de la pilastra hecho por Laborde (lám. CXXVIII, F), puede pensarse que el podio ocupado por la inscripción lleva en realidad una moldura corrida por su parte superior, que se corresponde con la inferior, y que ha sufrido una rotura en la parte central, de forma que los plintos de las basas y las mensulillas no serían sino restos de la moldura del podio. Las pilastras de las esquinas habrían tenido, por tanto, basas sin plinto, como las de las esquinas, más grandes.

(3) En la obra de Laborde se dice que el nicho de la torre de Daimuz estaba tapiado con una pared moderna y que tal vez estuviera aquí la puerta de la cámara interior por la que se intro- 


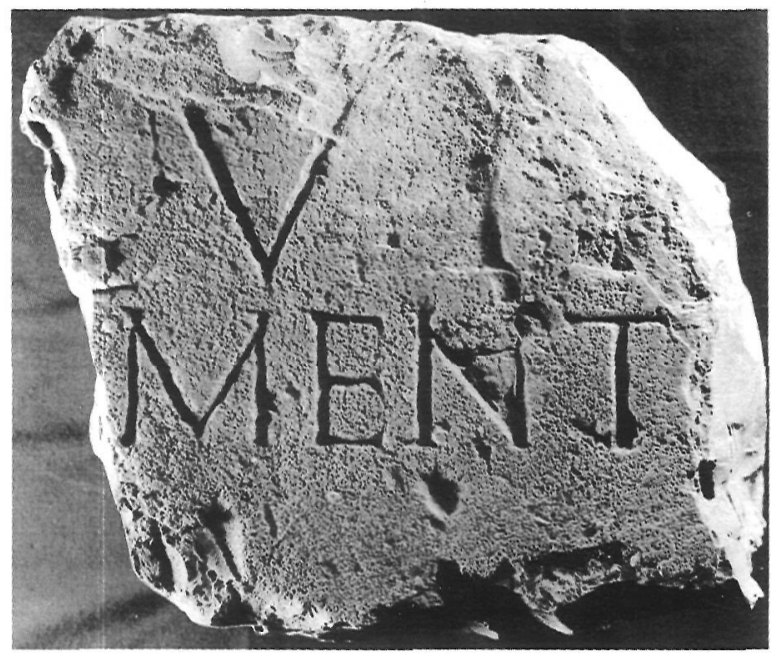

Fig. 6.-Fragmento de la inscripción de Daimuz, según Pons.

to suo, y dice de ella que corresponde «a una principal señora del linaje de los Bebios», del que se encuentran otras inscripciones en su obra (BEUTER, 1538, xvii). Posteriormente, el Conde de Lumiares la reproduce como Baebiae Quietae, ex testamento suo, decidiéndose por completar la I y la E de Quietae, que aparecen borradas en su reproducción gráfica (LUMIARES, sf, nr. 56). La misma lectura encontramos en el dibujo de A. de Laborde, aunque aquí aparece con todas sus letras; en cambio, en el texto, Baebiae quedará reducida a Bebiae (LABORDE, 1806, 48). Posteriormente, en el tomo II del CIL, Hübner recoge las diferentes lecturas anteriores y se decide por Baebiae - $f$. Quietae / ex testamento suo. Hay que suponer que Hübner -o su corresponsal- pudo ver la inscripción, que aún se conservaba in situ, y que por tanto debió tener sus motivos para corregir las lecturas anteriores. Todas ellas, y también la del propio Hübner, coinciden en mostrar las dos líneas de iguales dimensiones y con las letras de idéntica altura.

Sin embargo, un fragmento recientemente recuperado por F. Pons en las proximidades del monumento, y que se reproduce en la figura 6 , nos muestra las letras quie / mento y muestra claramente que las letras de la línea superior eran de mayor módulo, y se encontraban más espaciadas que las del inferior. Si observamos asimismo la colocación de las letras de las respectivas líneas, parece lógico deducir que difícilmente ambas podrían tener idéntica longitud, y que por el contrario el aspecto de la lápida debía ser bastante semejante al que reproducimos en la figura 7 , obra de F. Pons (PONS, 1973, sp.). Únicamente podría añadirse que, si existía la filiación, ésta debería ir en el espacio libre de comienzos de la primera línea, tras el cognomen, y no donde la sitúa Hübner, ya que entonces la disimetría entre ambas líneas se acentuaría aún más.

El fragmento recientemente recuperado tiene una altura de $28,5 \mathrm{~cm}$., equivalente aproximadamente a un pie romano, y es de piedra caliza gris,

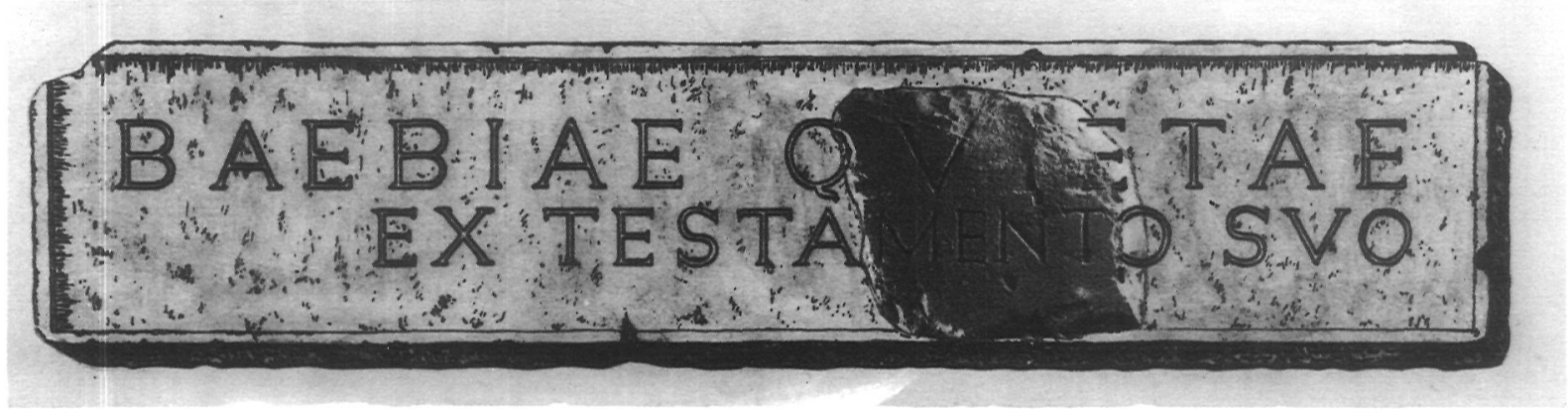

Fig. 7.-Reconstrucción de la inscripeión de Daimuz según Pons.

dujo el sarcófago, cosa bien improbable. En su dibujo de la lámina CXXVIII, A, se da a la zona del interior del nicho una apariencia distinta a la del resto de la fachada, sin indicar sillares, y lo mismo se observa en el menos preciso de la lámina CXXVI. Cabría suponer que lo que vieron los dibujantes eran restos de una posible decoración en relieve de estuco — como se supone también para el citado monumento de Tarragona- del que no sería extraño que quedaran trazas, dado el buen estado de conservación del monumento por entonces. Esta singularidad del nicho, frente a la desnudez de la piedra del resto de la construcción, es lo que pudo hacer pensar a Laborde que se trataba de una pared moderna. 
más oscura que la de los sillares que conformaban el monumento. Su espesor, de $12 \mathrm{~cm}$., y su reverso irregular, permiten suponer que se trataba de una placa de piedra - no un sillar- encastrada en el espacio que quedaba libre entre un basamento moldurado, las basas de las pilastras y dos pequeños sillares verticales que, por su singularidad, contribuían a realzar más la inscripción a la que servían de marco.

Queda claro, por tanto, que nos encontramos ante la mención del nombre de la persona para la que se construyó el monumento y de las circunstancias en que éste fue construido. El nomen Baebius y el cognomen Quietus son muy abundantes en la Península Ibérica, y especialmente en la costa mediterránea (CIL, s. v.). Ya Pons puso en relación la Baebia Quieta de nuestra inscripción con un M. Baebius Quietus de una inscripción de Liria (CIL, II, 3797), al que podríamos añadir también la Baebia Cn. 1. Quieta del Puig de Cebolla (CIL, II, 3962) y la Baebia M.f. Quieta de Tarraco (CIL, II, 4340). Es interesante indicar que entre ellos existen nombres de libertos y de libres, y que posiblemente debieron guardar alguna relación con los Baebii de Sagunto estudiados por Alföldy (1977), aunque ninguno de los personajes saguntinos de este nombre lleve el cognomen de Quietus (BELTRÁN LLORIS, 1980).

\section{LA TORRE DE VILLAJOYOSA}

\subsection{Historia de la investigación}

Conocida desde antiguo con el nombre de «Torre de San José», se ha incorporado a la bibliogra-

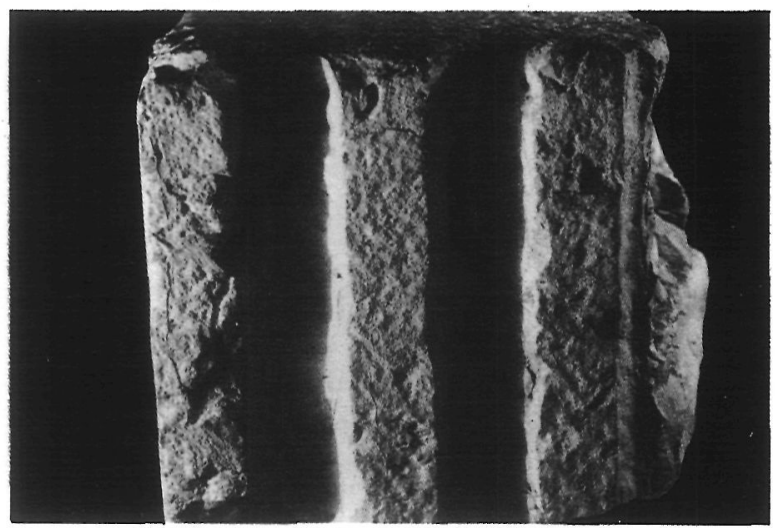

Fig. 8.-Fragmento de una de las pilastras de Daimuz, según Cardona. fía reciente como «Torre de Hércules», por el apellido de su propietario, y aún se conserva en bastante buen estado, aunque parcialmente oculta por edificaciones modernas. En los primeros años del siglo XVII, el cronista Escolano (1610, VI, XII, 7) utiliza el monumento como argumento para localizar en Villajoyosa la ciudad de Ionosa u Honosa. Dice que los romanos reedificaron esta ciudad

«como parece por las piedras y de sus fábricas que de su tiempo nos han quedado, mayormente por una torre que en el sitio viejo de esta población se tiene aún en pie, pero muy arruynada; a quien los nuestros llaman corrompidamente la torre de Ioseph, por dezir de Iosa. Segunda vez en otras guerras pagó la segunda paga al tiempo, y fue destruyda: y son tantas las pied ras que de sus ruynas andan sembradas por aquel suelo que los navíos que por allí tocan cargan dellas para lastre. En el año 1543, cavando los de Villajoyosa en estas ruinas por llevar las piedras para la cerca de la villa, que después se hizo, en el sitio que agora la vemos un poco apartada del viejo, descubrieron junto a dicha torre de Ioseph unos muy grandes y sumptuosos sepulcros, de los quales como de una oficina de cantería sacaron la que huvieron menester, cortada ya y labrada. A bueltas destas se llevaron una muy ancha y larga, con un letrero famoso: la qual pusieron en ell altar mayor de su iglesia, y dize: M. Sempronius Hymnus et $\mathbf{M}$. Reburri eius filii nomine sua $\mathbf{M}$. Marcellum vetustate conlapsum pecunia restituerunt etiamque mensas lapideas posuerunt, que quiere dezir: Marco Sempronio Himno, en nombre suyo y de su hijo Marco Reburro, restituyó de su dinero la estatua que estaba dedicada al gran cónsul romano M. Marcelo, que de vieja se havía caydo. Y assimismo los dos pusieron delante de dicha estatua o altar, las mesas de piedra» (ESCOLANO, 1610, VI, XII, 7).

De las palabras de Escolano, dejando aparte la curiosa etimología y la no menos curiosa interpretación de la inscripción, a las que más adelante nos referiremos, se deduce que la torre de San José formaba parte de una necrópolis y que en sus proximidades apareció la inscripción ya citada.

Años más tarde, ya a finales del siglo XVIII, Antonio de Valcárcel, Conde de Lumiares, describía el monumento de la siguiente manera (figs. 9 y 10):

«Sepulcro romano a quien el vulgo llamaba Torre de San José. A un cuarto de legua hacia Poniente y a trescientos cincuenta pasos del mar, se halla este monumento de indudable antigüedad y hasta ahora 

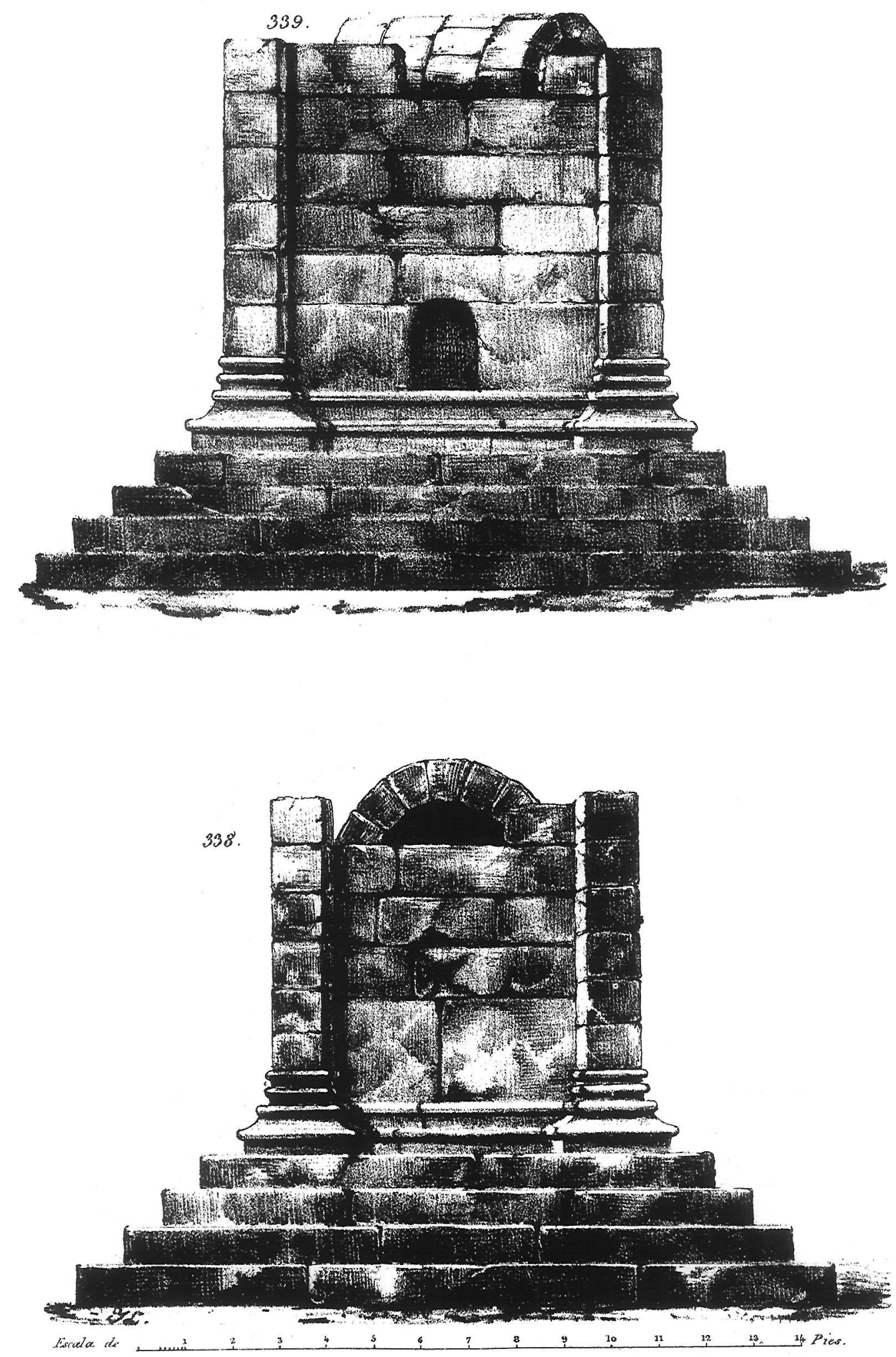

Fig. 9.-El monumento de Villajoyosa, según Lumiares. 

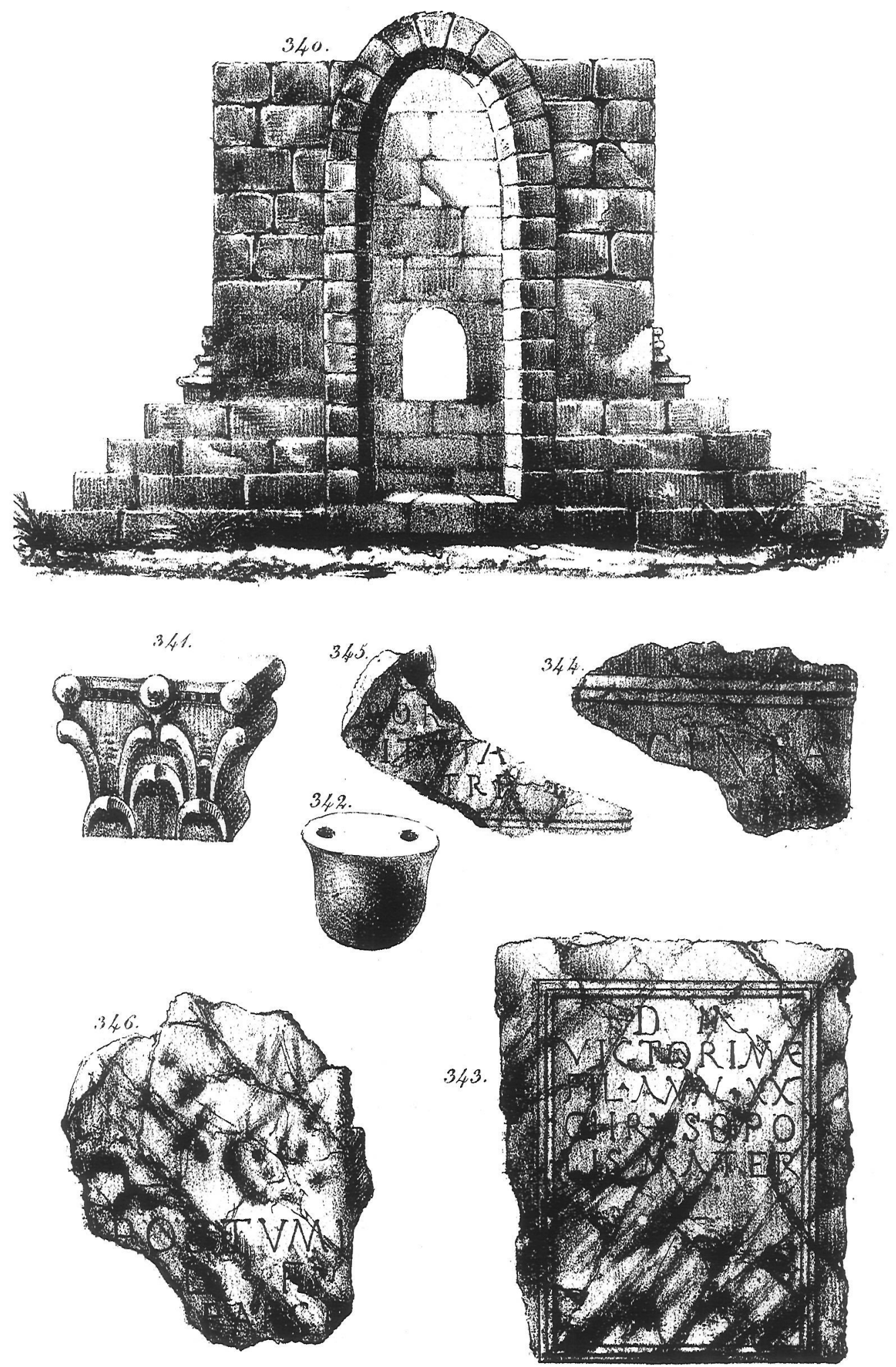

Fig. 10.-El monumento de Villajoyosa, según Lumiares. 
desconocido: no es perfectamente cuadrado, pues dos de sus fachadas tienen doce pies y cuatro pulgadas; y las otras dos diez pies y nueve pulgadas. En las de los dos lados, que son más estrechas, hay en cada una un respiradero a la elevación de diez pies, que tiene la dirección hacia arriba, de suerte que mirando por la parte interior no se puede ver más que el cielo. A la parte del Norte está la puerta del ingreso al sepulcro, al cual no se puede bajar sin escala, no porque se haya destruido, sino porque jamás la hubo, pues la obra está interiormente perfectamente conservada. El vaso interior es un cañón de doce pies y dos pulgadas de alto, cinco pies ancho y de ocho pies de largo: el espesor o grueso de las murallas es de dos pies y cinco pulgadas. La sillería sumamente grande de las mismas piedras, que manifiestan los diseños, la obra solidísima y su estructura de la llamada por los antiguos pseudoisódoma, es decir que las hiladas de piedras son desiguales en altura: las cuatro fachadas son conformes en arquitectura, de suerte que por todos lados forma igual figura; las cuatro gradas circuyen el edificio, de modo que el arca o cuadrilongo que ocupa es de veinte y dos pies de longitud, y veinte pies de latitud. Al nivel del piso sube una hilada de cantería, sobre la cual arranca la primera grada; esta hilada de cantería descansa sobre un cimiento de obra cimenticia, o sea hormigón de mortero, de ocho pies de profundidad; fáltale a este edificio parte de su cúpula, y los naturales ancianos aseguran que en cada uno de sus ángulos había una pilastra con su estatua, y aunque no me parece natural, sin embargo quedan algunos fragmentos de estatuas entre aquellas ruinas y dos capiteles, uno encajado en la pared de la cerca de la casa contigua y otro al pié de la noria, como representa el número 341, pero no me parecen de aquel tiempo» (VALCÁRCEL, sf, 101).

A comienzos del siglo XIX, A. de Laborde se refiere en su obra ya citada a este mismo monumento, que pone en relación con el de Daimuz (figs. 11 y 12). Su descripción es como sigue:

«Une demi-lieue avant d'arriver à Villa-Joyosa, petite ville entre Dénia et Alicante, on trouve au bord de la mer cette construction d'origine romaine, et nommée aujourd 'hui Torre de San Ioseph; c'est un monument carré du même style que celui de Dayemus, ayant de même, à chacun de ses angles, un pilastre d'ordre corinthien, et bâti en pierres d'une belle qualité et fort bien travaillées. La base, formée de quatre marches ou gradins, est parfaitement conservée; mais le corps de l'édifice n'existe que jusqu'aux deux tiers de la hauteur des pilastres, dont les chapiteaux, ainsi que l'entablament on été enlevés, et se trouvent épars dur le terrain ou dans les bâtiments adjacents. D'ailleurs ces fragments, dont le travail n'a point reçu sa perfection, annoncent par l'etat où ils sont que l'édifice n'avoit point été fini: c'est seulement par l'analogie qu'il offre avec le monument de Dayemus que nous avons jugé que c'étoit un tombeau, car rien dans ses détails ni aux environs n'annonce positivement quelle fut sa destination. Il sert aujourd'hui de grenier et de cave à un meunier.

\section{PLANCHE CXXXV}

A. Plan et élévation géométrale dudit tombeau.

B. Chapiteau qui se trouve compris aujourd'hui dans un mur auprès de la porte d'entrée de la base-cour: il n'est absolument qu'ebauché, et prêt à recevoir les détails de la sculpture.

C. Fragment qui a servi de corniche ou de base à quelque piédestal.

D. . Autre fragment qui paroît avoir fait partie de l'entablement de l'édifice.

E. Pierre qui terminoit très probablement le pilastre, et se trouvoit au dessous du chapiteau.

La voûte en plein ceintre qui couronne le monument est en pierres de taille et bien conservée; sa hauteur, depuis le sol où posent les bases des pilastres, est de 21 pieds» (LABORDE, 1806, 49).

\subsection{Descripción}

Los dibujos de Lumiares y Laborde, y la observación de los restos del monumento aún existentes (figs. 13 y 14), permiten obtener una idea bastante aproximada de su aspecto y estructura.

Especialmente importantes son la descripción y los dibujos de Lumiares, ya que reproducen el monumento cuando éste se encontraba completamente exento, aunque los detalles no coinciden del todo con la realidad. En las figuras núms. 338 y 339 se representa el monumento cubierto por una bóveda de sillería, en dirección $\mathrm{E}-\mathrm{O}$, que se conservaba aún en pie pese a que las paredes exteriores habían sido desmontadas hasta un nivel inferior al de la clave de la bóveda. La figura 340 muestra el monumento cortado por el centro, y parece como si la bóveda fuera la cubrición de una cámara interior independiente de las paredes exteriores; al fondo se aprecia una pequeña entrada y más arriba una ligera rotura en uno de los sillares. En la figura 341 se reproduce un capitel que a Lumiares no le parece «de aquel tiempo». 


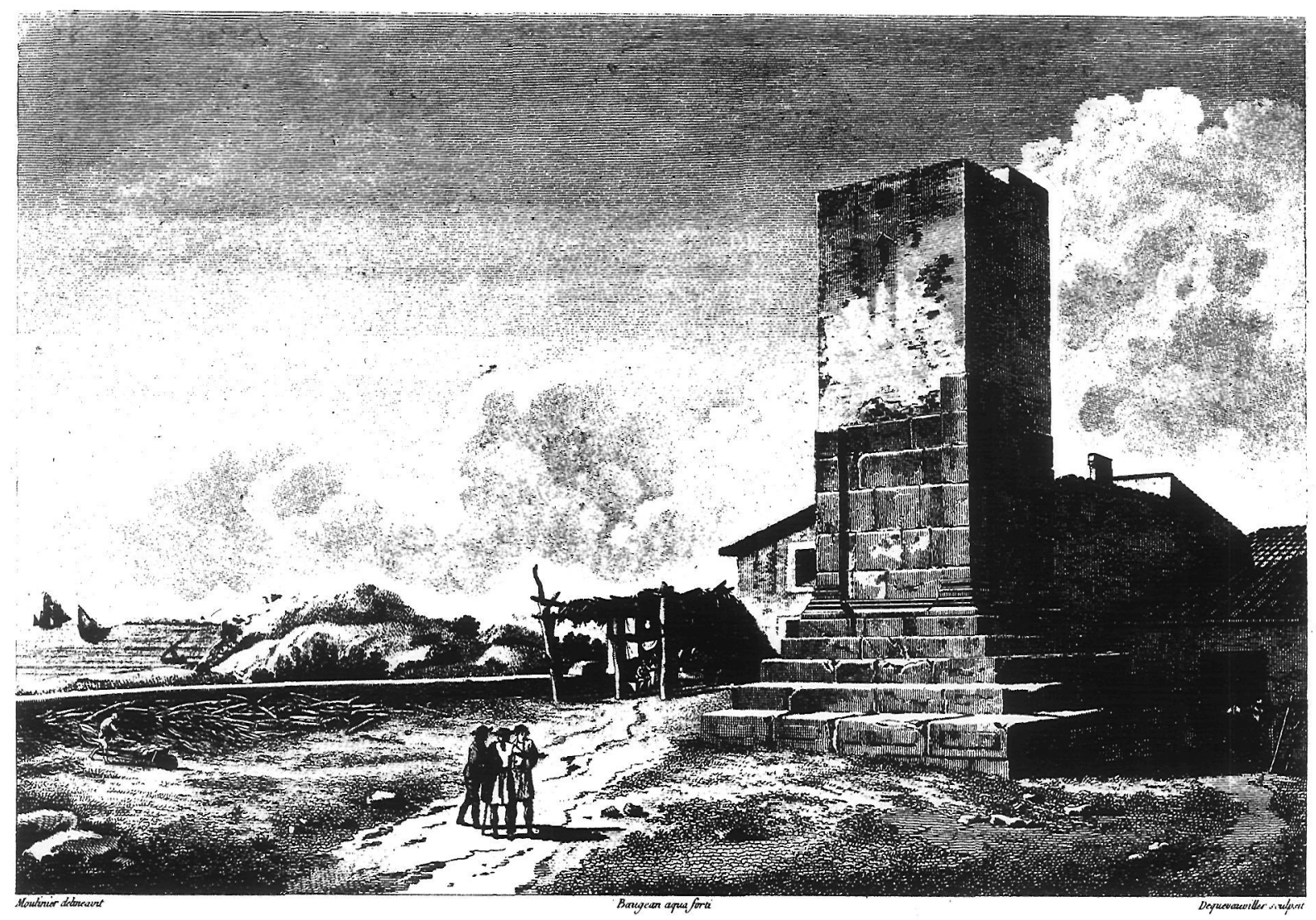

Fig. 11.-El monumento de Villajoyosa, según Laborde.

Cuando algunos años después Laborde vuelve a dibujar la torre, ésta se encuentra ya adosada por una de sus caras a un edificio moderno y ha recibido un segundo cuerpo de mampostería que oculta al exterior la bóveda reproducida por Lumiares. En su dibujo se observa que el podium constaba de cuatro escalones, el inferior de los cuales conservaba aún el almohadillado rústico. En la cara norte, se representa la estrecha oquedad ya vista en Lumiares, que constituye el único acceso al interior del edificio. Entre los detalles de la lámina CXXXV se incluyen un capitel y fragmentos de diversas molduras. Aunque no la reproduce, Laborde habla de que la bóveda de arco de cañón que corona el monumento es de piedra de talla y estaba muy bien conservada.

En su estado actual, el monumento se alza sobre un basamento escalonado con cuatro gradas, la inferior de las cuales - almohadillada según los dibujos de Laborde- queda oculta por el suelo actual. En la grada superior reposa el basamento del cuerpo principal de la torre, retranqueado también respecto de su base, aunque en menor medida que lo hacen los demás escalones. La planta de este basamento queda articulada con objeto de configurar en las esquinas soportes diferenciados para las pilastras, y se corona por una moldura de talón, o cyma recta, que recorre todo su contorno ajustándose a sus entrantes y salientes. El cuerpo principal, de planta rectangular como todo el monumento, queda definido por cuatro pilastras de esquina, de orden corintio; sus fustes son lisos y las basas, con plinto, de tipo ático. Es de destacar que todas las molduraciones, tanto en las basas como en el basamento articulado, presentan perfiles tensos, con preferencia por las formas rectas sobre las redondeadas. Los cuatro paños entre las pilastras son lisos, sin decoración alguna, a diferencia de la fachada principal del monumento de Daimuz. La cara oriental presenta, a la altura de la unión de las hileras segunda y tercera del cuerpo principal, un pequeño orificio algo desplazado a la derecha respecto del eje central; se trata de un conducto que atraviesa el muro en vertiente hacia el interior, rea- 


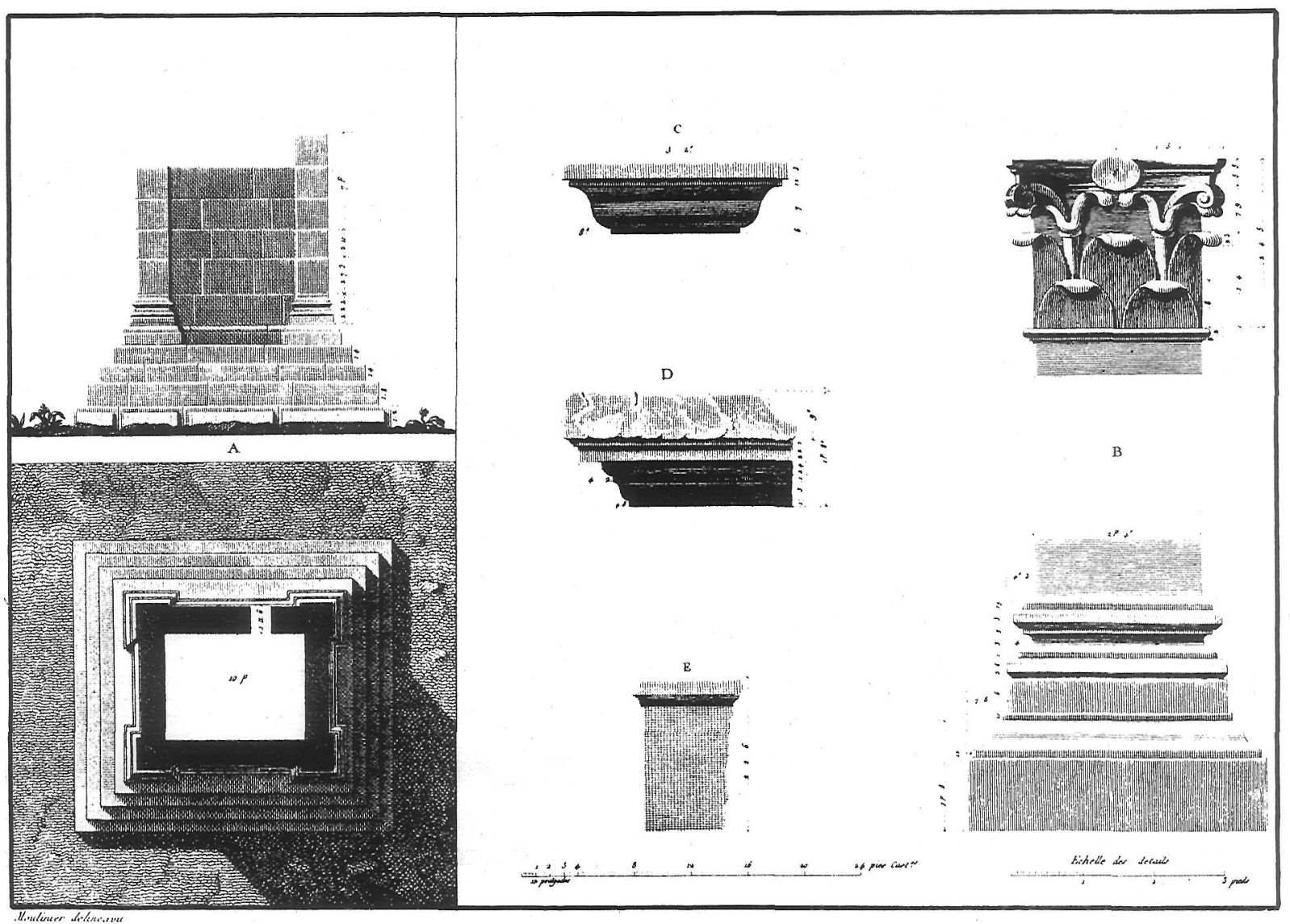

Fig. 12.-Detalles del monumento de Daimuz, según Laborde.

lizado según se indica en el dibujo de la figura 15; aprovechando la unión horizontal de dos sillares se perforó oblicuamente la parte exterior del de arriba, y a continuación la superior del situado debajo, de forma que las bocas de entrada y de salida quedan en posición invertida fuera y dentro del muro respecto de la línea de unión de los sillares. Debe de tratarse de un conducto para libaciones, de donde su particular estructura. El Conde de Lumiares indica que había otro igual en la cara opuesta de la torre, cosa que no hemos podido comprobar ni por el interior, parcialmente oculto por los pisos y escalerilla modernos, ni por el exterior, tapado de igual modo por la nueva edificación.

En la cara norte, encalada y casi totalmente cubierta por las construcciones que se le adosaron, se halla el único acceso al interior de la torre. Es, sin duda, un portillo moderno realizado para el saqueo y posterior aprovechamiento de la cámara interior. La perforación, irregular y difícilmente practicable, se hizo a la altura de la primera hilada de sillares del cuerpo principal, y no en el centro de la fachada, como se indica en los dibujos de Lumiares, sino desplazada hacia la pilastra del ángulo nordeste; véase su posición en el dibujo, más correcto, de la lámina $\mathrm{CXXXV}$, $\mathrm{A}$ de Laborde, y en nuestra sección horizontal de la figura 16, donde el portillo queda marcado en punteado.

El interior de la torre se encuentra bastante alterado por la utilización que de ella se ha hecho a lo largo de los tiempos; sabemos por Laborde que a comienzos del siglo XIX servía de granero y de almacén a un molinero, y su empleo como almacén ha perdurado hasta tiempos bien recientes. Consta de una única cámara cerrada por su parte superior por una sólida bóveda de cañón, de sillería, apeada en los lados mayores, que arranca directamente de la quinta hilada de sillares del cuerpo principal del monumento. Sus dimensiones son $2,76 \mathrm{~m}$. de largo, $1,60 \mathrm{~m}$. de ancho y $7,50 \mathrm{~m}$. de altura, medida esta última desde el punto más alto del intradós de la bóveda hasta el nivel de suelo actual, producto 


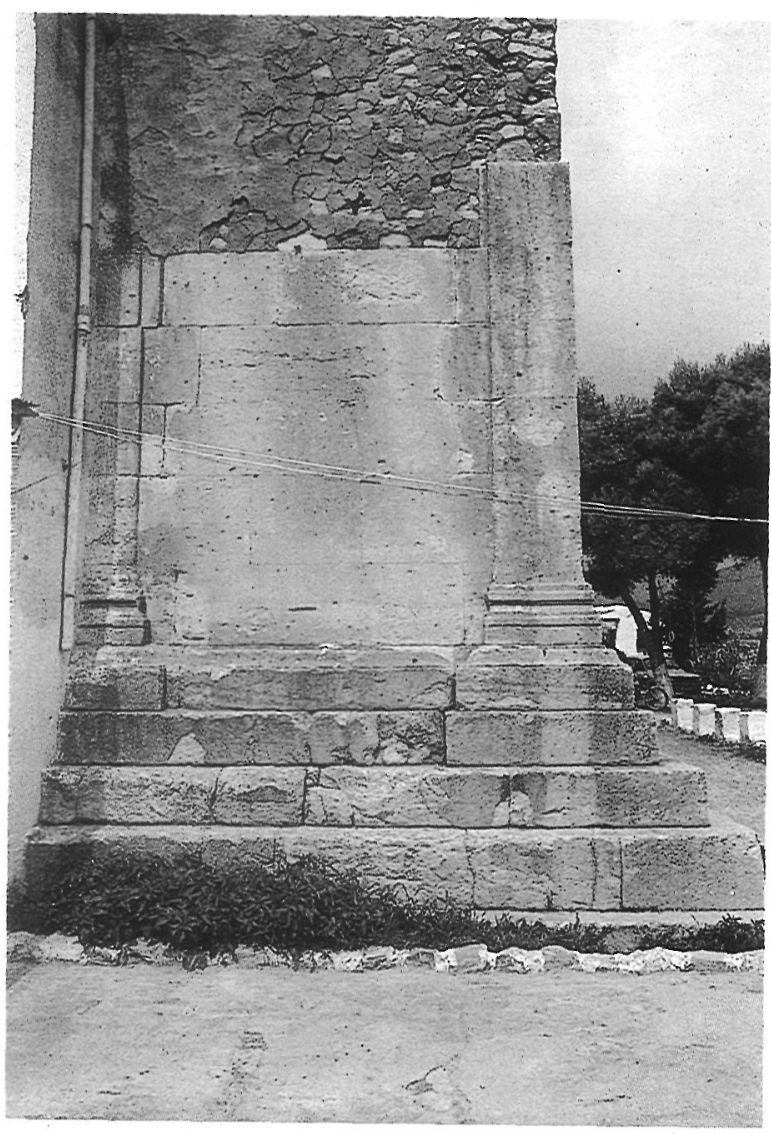

Fig. 13.-Vista del monumento en su estado actual.

de una acumulación de escombros sobre el original. La cámara se encuentra hoy dividida horizontalmente por dos pisos modernos, uno a $1,75 \mathrm{~m}$. y otro a 4,10 m. desde el punto central de la bóveda, este último inmediatamente por debajo del portillo de acceso; todos ellos deben ser añadidos posteriores a la fecha de la descripción de Lumiares, ya que éste alude a un interior único (4).

Pese a los añadidos modernos, es posible analizar, siquiera sea parcialmente, la estructura de la bóveda. La rosca queda compuesta por series de cinco grandes dovelas, tallados los salmeres de for-

(4) Por el portillo moderno se accede hoy a la cámara central, y desde aquí, a través de una escalerilla, acodada en el ángulo SO, a la superior, desde la que se puede examinar la bóveda original. Sobre los restos de la construcción moderna se levantó una nueva dependencia, ya reflejada por Laborde, que se comunicaba con el compartimiento superior de la cámara a través de una angosta escalerilla, hoy clausurada, practicada en el lado oeste, en el hueco resultante de la remoción de los sillares de este sector.

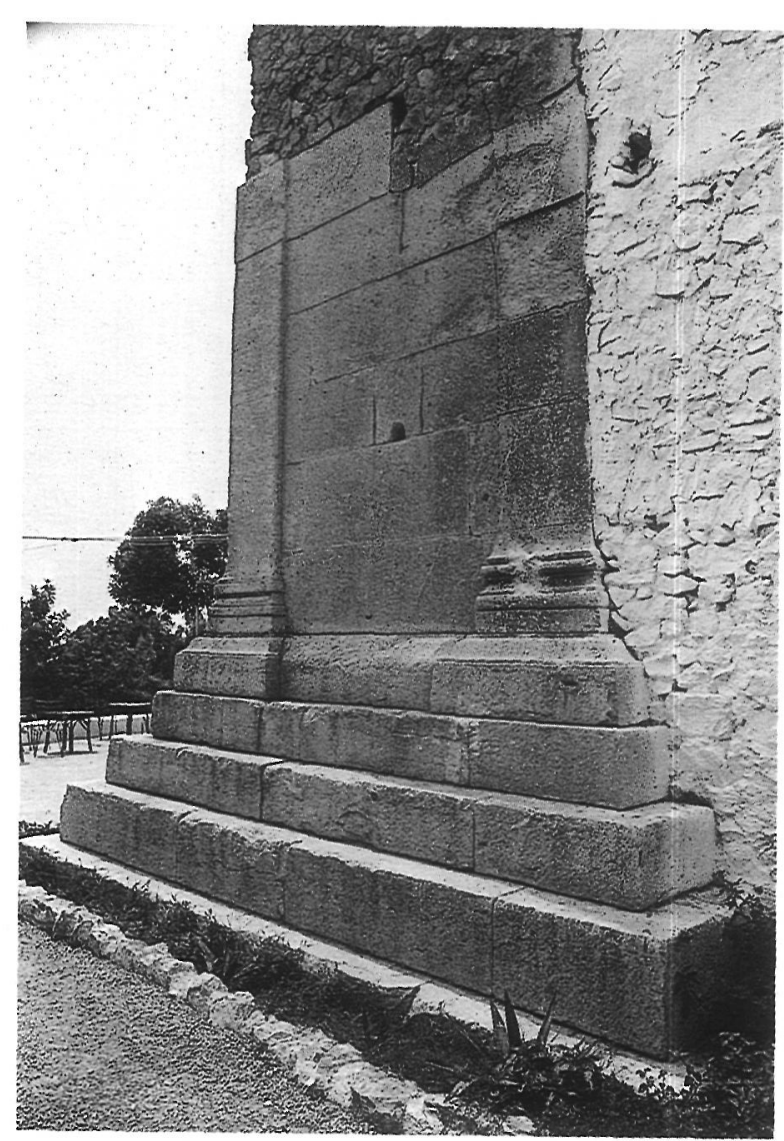

Fig. 14. - Vista del monumento en su estado actual.

ma que por la cara exterior se integran como una hilada más a los sillares de fachada y por la interior se curvan como arranque de la bóveda. Tanto los salmeres como los sillares inmediatamente superiores tienen en el trasdós escalonamientos y entalladuras para facilitar el apeo de los sillares superiores de la torre, como se indica en la sección de la figura 23. Todo el edificio está realizado con sillares de piedra caliza dolomítica, extraídos de las canteras próximas.

\subsection{Restos arquitectónicos conservados en las proximidades}

A. de Laborde reproduce, en su lámina $\mathrm{CXXXV}$, una serie de elementos arquitectónicos conservados en las proximidades del monumento que debieron pertenecer al propio sepulcro o, en todo caso, a monumentos próximos. Muchos de estos restos se conservan aún en un jardincillo en los alrededores de la torre, pues fueron recupera- 


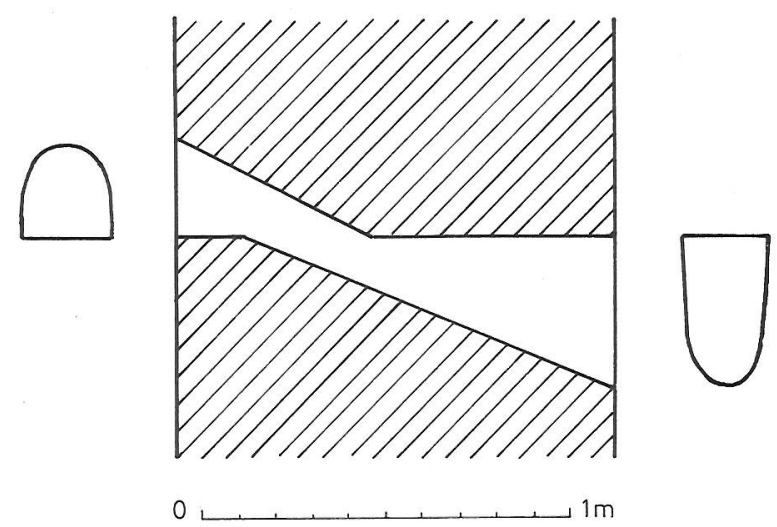

Fig. 15.-Esquema del orificio de libación del monumento de Villajoyosa.

dos por sus actuales propietarios al desmontar construcciones adosadas al monumento. También se conservan otros que no fueron dibujados por Laborde y que en algunos casos parecen corresponder al propio mausoleo. Son los siguientes:

1. Capitel de pilastra (figs. 17 y 18), de la misma piedra que los sillares del edificio. Es de tipo corintio, con dos hileras de anchas pencas de extremos vueltos hacia el exterior, caulículos, hélices y volutas someramente labrados, y un óvalo correspondiente a la flor del ábaco; este último viene indicado por un ligero resalte en la parte superior del capitel. Se conserva en relativo buen estado una de las caras exteriores, aunque con erosiones sobre todo en los extremos de las pencas, y roturas diversas, la más importante en la parte superior derecha. El otro frente ha desaparecido casi por completo -apenas se conserva un tercio- debido a reutilizaciones y retalles modernos que también afectan a a las dos caras interiores. En la superior existe una cavidad en forma de cola de milano para la suspensión de la pieza durante los trabajos de construcción. Las medidas del capitel son $82 \mathrm{~cm}$. de largo, 65 de alto y 87 de grosor.

El Conde de Lumiares se refiere (sf. 101) a la existencia de dos capiteles, «uno encajado en la pared de la cerca de la casa contigua y otro al pie de la noria», aunque a él no le parecen «de aquel tiempo». Reproduce uno de ellos ( $\mathrm{n} .^{\circ} 341$ ), que difiere bastante del actualmente conservado, aunque podría corresponder a una interpretación libre -y bastante torpe- del mismo. Laborde (1806, CXXXV, B) dibuja también un capitel, pero bastante más elaborado que el de Lumiares: los caulí- culos están ya claramente diferenciados y las volutas terminadas, aunque aún quedan por completar las hojas de acanto y la flor del ábaco. El aspecto final del capitel de Laborde, una vez terminado, debería ser bastante similar al que el propio autor

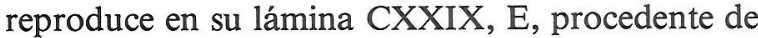
Daimuz, lo que nos hace entrar en sospechas que más adelante, en el estudio de los capiteles, detallaremos.

2. Fragmento de un arquitrabe (fig. 19, a). En el frente lleva las características platabandas coronadas por una sencilla moldura biconvexa y un filete. En la parte superior presenta un hueco en forma de cola de milano semejante al de la pieza anterior. Este fragmento no se encuentra entre los dibujados por Laborde, pero corresponde claramente el arquitrabe de un edificio de orden corintio y por ello y por sus proporciones bien pudo corresponder a nuestro monumento. Mide $90 \times 50 \times 61$ centímetros.

3. Fragmento de una cornisa (fig. 19, b), con una sucesión de molduras que de abajo arriba son: una moldura de talón entre filetes, un cuarto de bocel y dos filetes de diferente altura; la parte superior, hoy rota, debió consistir en una moldura de talón entre filetes. Esta pieza debe corresponder a la dibujada por Laborde en su lámina CXXXV, D. Mide $93 \mathrm{~cm}$. de largo, 43 de altura y 67 de profundidad en su parte inferior (86 en la superior, hasta la rotura).

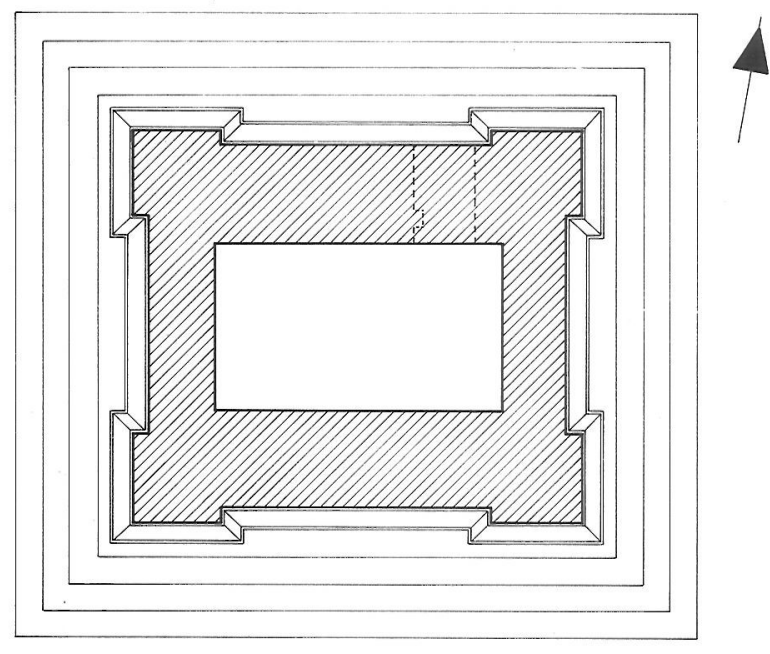

Fig. 16.- Sección del monumento de Villajoyosa con indicación del portillo moderno de acceso. 


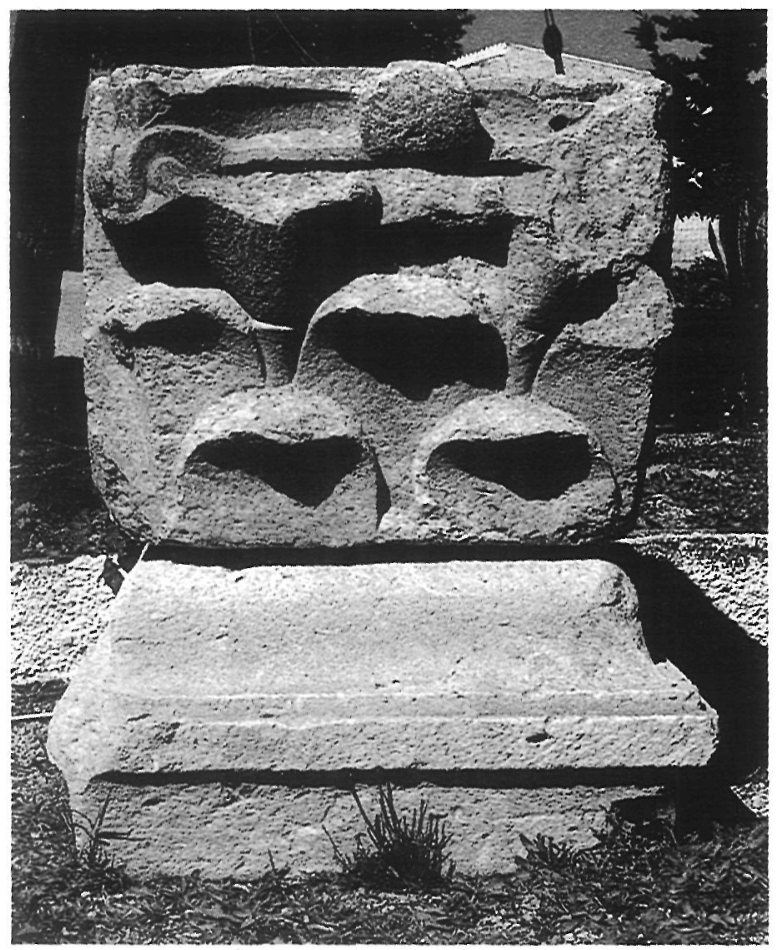

Fig. 17.-Capitel conservado del monumento de Villajoyosa.

4. Pieza fragmentada que debió formar parte de un pedestal y se halla hoy, invertida, sirviendo de soporte al capitel de pilastra antes descrito (fig. 20, b). Conserva un frente completo, de 90 $\mathrm{cm}$. de longtud, y los dos laterales interrumpidos por la rotura hasta distancias de 70 y $60 \mathrm{~cm}$. en uno y otro lado, respectivamente. Por debajo, una amplia cyma recta de perfil con curvas muy pronunciadas, entre filetes, rematada por una moldura plana sobre la que asienta un ancho remate de caras oblicuas.

5. Fragmento de sillar reproducido por Laborde (CXXXV, E), que lo considera como el remate del fuste de una pilastra. No se conserva.

6. Pedestal anepígrafo con una cavidad en forma de cola de milano en su parte superior (fig. 20, a). En cuerpo central, prismático, lleva arriba y abajo, entre filetes, sendas molduras de talón poco pronunciadas. Apoya sobre plinto liso y remata en su parte superior en un cuerpo de paredes ligeramente oblicuas.

7. Existen asimismo numerosos sillares, de dimensiones variadas, pero siempre relacionables
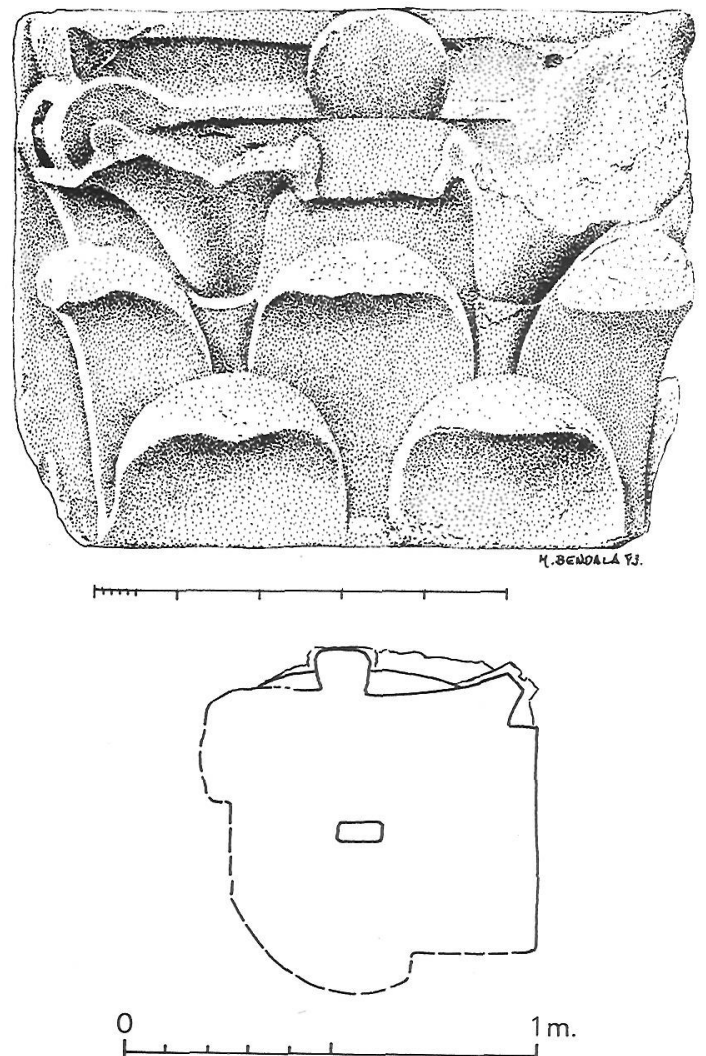

Fig. 18.-Visión frontal y superior del capitel anterior.

con las de los que se conservan in situ en el monumento. Uno de ellos muestra un rehundimiento en una de sus caras, de tres $\mathrm{cm}$. de profundidad, bordeado por una cenefa de entre 18 y $33 \mathrm{~cm}$. de ancho, correspondiente a la superficie original del sillar. Podría pensarse que nos encontráramos ante el alojamiento de una placa de mármol, posiblemente con inscripción, pero de ella no queda resto alguno.

\subsection{Reconstrucción del monumento}

Combinando los restos conservados in situ y las piezas números 1 (capitel), 2 (arquitrabe) y 3 (cornisa), cuyas dimensiones y tipo de piedra permiten adscribirlas al monumento, es posible intentar la reconstrucción de la parte superior perdida con un alto grado de verosimilitud, tal y como se propone en las figuras 21 y 22 . A lo conservado se ha añadido una hilada más de sillares, porque así lo sugiere el ritmo general del edificio y lo exige la altura de la bóveda. Para la reconstrucción del friso se han utilizado sillares lisos de dimensiones próximas a las 
del arquitrabe y la cornisa, y se ha supuesto que el edificio remataba en un piramidium, por las razones que más adelante se expondrán, aunque no se conserva ningún resto del mismo. La altura de este piramidium, y la de todo el edificio, se ha determinado en función de los estudios metrológicos que a continuación se exponen.

\subsection{Metrología}

Es sumamente difícil realizar una reconstrucción metrológica del edificio, pues falta casi toda su parte superior. Las medidas que dan un número más exacto de pies son la altura de la grada escalonada, con siete pies hasta la parte inferior de la gola que marca el tránsito entre esta parte del edificio y el cuerpo principal, la altura de las basas de las pilastras, con dos pies, y la anchura del cuerpo principal del edificio, con 13,5 pies. La anchura del podium en el escalón inferior es de 21,75 pies en la cara más ancha y de 19,75 en la más estrecha, en tanto que en la grada superior es de 15,59 y 13,95, respectivamente. Existen algunas diagonales que parecen ajustarse a unas determinadas proporciones; así, una línea imaginaria que arrancara desde el ángulo inferior izquierdo alcanzaría los 20 pies en el extremo superior externo de la basa de columna opuesta, los 30 en el extremo superior del capitel del mismo lado y los 35 en el de la cornisa que hemos reconstruido. Para el extremo superior del piramidium se ha supuesto una diagonal de 45 pies, lo que nos daría una altura total del edificio de 43,5 pies, con una relación de $2: 1$ con respecto a
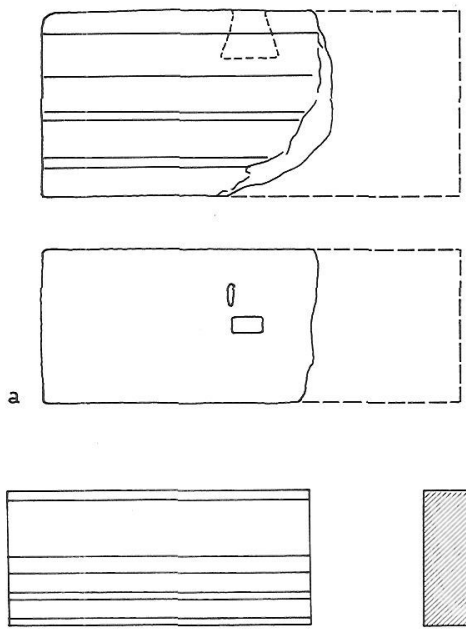

b

Fig. 19.-Arquitrabe (a) y cornisa (b) del monumento de Villajoyosa. su anchura máxima. Con esta altura, el cuerpo principal del monumento, incluyendo basa y capitel, sería de 17,5 pies, y de 15,5 excluida la primera; arquitrabe, friso y cornisa alcanzarían un total de 5,5 pies, en tanto el piramidium alcanzaría los 13,5 pies. Todas estas proporciones son, no obstante, meramente aproximadas, ya que no existe ninguna relación proporcional fija entre las diferentes partes de estos edificios.

\subsection{Inscripciones}

Los monumentos de este tipo solían llevar una o varias inscripciones funerarias, como ocurre en el de Daimuz, labradas o bien en los sillares del propio cuerpo del edificio, o bien en el friso o en otro lugar destacado. No conservamos resto algu-
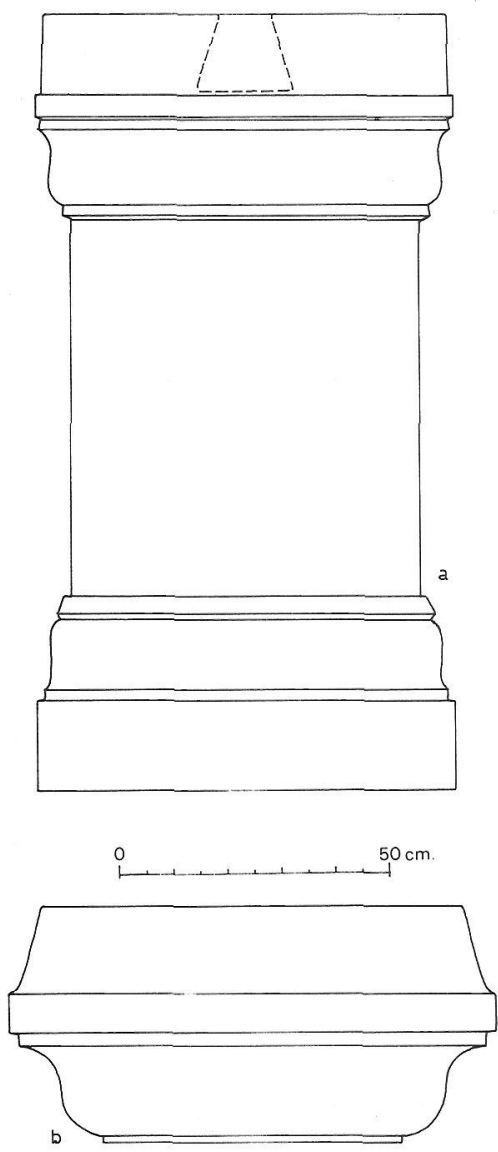

Fig. 20.-Ara (a) y pieza indeterminada (b) del monumento de Villajoyosa. 
no de la inscripción del monumento de Villajoyosa - si es que la hubo-, aunque como se ha indicado en el apartado 2.3.7, uno de los sillares que se encuentran en las proximidades muestra un rehundimiento en su cara principal que pudo servir de alojamiento a una placa con inscripción.

La única inscripción que las fuentes relacionan con el monumento es la CIL II, 3570, a la que ya hemos aludido en la descripción de Escolano. Su lectura, M. Sempronius Hymnus / et M. Reburri eius filii / nomine sua $M$. Marcel / lum vetustate conlap / sum pecunia restitue / runt etiamque et men / sas lapideas posuerunt (ESCOLANO, 1610, VI, XII, 7), fue ya corregida por Lumiares (sf, 331), cuya lectura se corresponde con la que dio Hübner en el CIL: $M$. Sempronius Hymnus suo et M. Semproni Reburri / fili sui nomine macellum vetustate conlap / sum sua pecunia restituerunt item / que et mensas lapideas posuerunt. Con ello desaparece el supuesto nombre de Marcelo - aunque aún hoy se aprecia en la lápida que alguien cinceló una $r$ junto a la $a$ de macellum-y el pretendido carácter histórico de la inscripción, para convertirse en el simple testimonio de la reconstrucción de un mercado y de la colocación en el mismo de mesas de piedra (cf. DE RUYT, 1983).

El nomen Sempronius se encuentra enormemente extendido por todo el Imperio, no así los cognomina atestiguados en la inscripción. Hymnus, de origen griego, sólo se encuentra en España en otra ocasión, sobre un sello de bronce (CIL, II, $6259,13)$, y Reburrus, mucho más frecuente, parece ser de origen hispano, muy posiblemente indígena, y es especialmente abundante a fines del siglo I y durante todo el II entre las poblaciones del noroeste peninsular (RUBIO ALIJA, 1959, 43 ss.)

Más que la lápida en sí, nos interesan en este momento las noticias que transmite Escolano en torno a las circunstancias de su aparición. Según él, se encontró junto a la torre de San José, en relación con unos «muy grandes y sumptuosos sepulcros» que sirvieron de cantera para la muralla de la ciudad. Si realmente se tratara de sepulcros, ello nos confirmaría que la torre estaba dentro de un área de necrópolis, como por otra parte parece lógico suponer. Sin embargo, no tenemos noticias de que modernamente se hayan encontrado otros restos de edificios en la zona, y tampoco Escolano especifica en qué se basa su afirmación de que se.trata de sepulcros. Desde luego, la lápida no puede relacionarse con una construcción funeraria, y su forma permite suponer que se trataba de una de las mensae lapidae a que en ella se alude (cf. RUYT, 1983, 318 ss., figs. 101-102). En este caso habría que pensar que el mercado y las tumbas se encontraban juntos o muy próximos, lo que tampoco parece probable. Carecemos igualmente de datos para pensar que se trate de una inscripción reutilizada en un edificio funerario. Son todos ellos problemas que desbordan el marco de este estudio y que nuevas investigaciones deberán plantear y resolver.

\subsection{La cerámica}

En el Museo Etnológico de Villajoyosa se conservan cinco recipientes cerámicos que, según las noticias proporcionadas por D. Manuel Arteseros y D. José Payá, aparecieron en el interior de la torre hace algunos años, cuando se procedió a una limpieza superficial de la parte inferior de la cámara. Son los que se reproducen en la figura 24 , y su mera contemplación basta para concluir que no se trata de materiales de época romana. Algunos detalles, como la forma de las vasijas núms. 2 y 3, y la decoración de la 2 (vidriado muy perdido), 3 y 4 (restos de pintura de colores negro y verde oscuro, respectivamente) permiten suponer que corresponden a una época bastante avanzada de la Edad Media, cuando no a inicios de la Edad Moderna. En este sentido, puede compararse la forma de la vasija número 2 con las de algunas cerámicas catalanas del siglo XIV (RIU, 1984, 171, nr. 30 y 31).

No realizaremos, por quedar fuera del objeto de este artículo, un estudio detenido de estas cerámicas. Bástenos presentarlas como testimonio de un reaprovechamiento del edificio en una fecha bastante tardía, que no debió ser ni el primero ni el último.

\section{LOS ELEMENTOS DECORATIVOS: CAPITELES, BASAS Y MOLDURAS}

\subsection{Los capiteles}

De cada uno de los monumentos conocemos dos capiteles, de los cuales tan sólo uno de Villajoyosa se conserva en la actualidad.

Los capiteles de Daimuz se conocen a través de los dibujos de Laborde (1806, lám. CXXIX B y, especialmente, E). Son capiteles de esquina de or- 


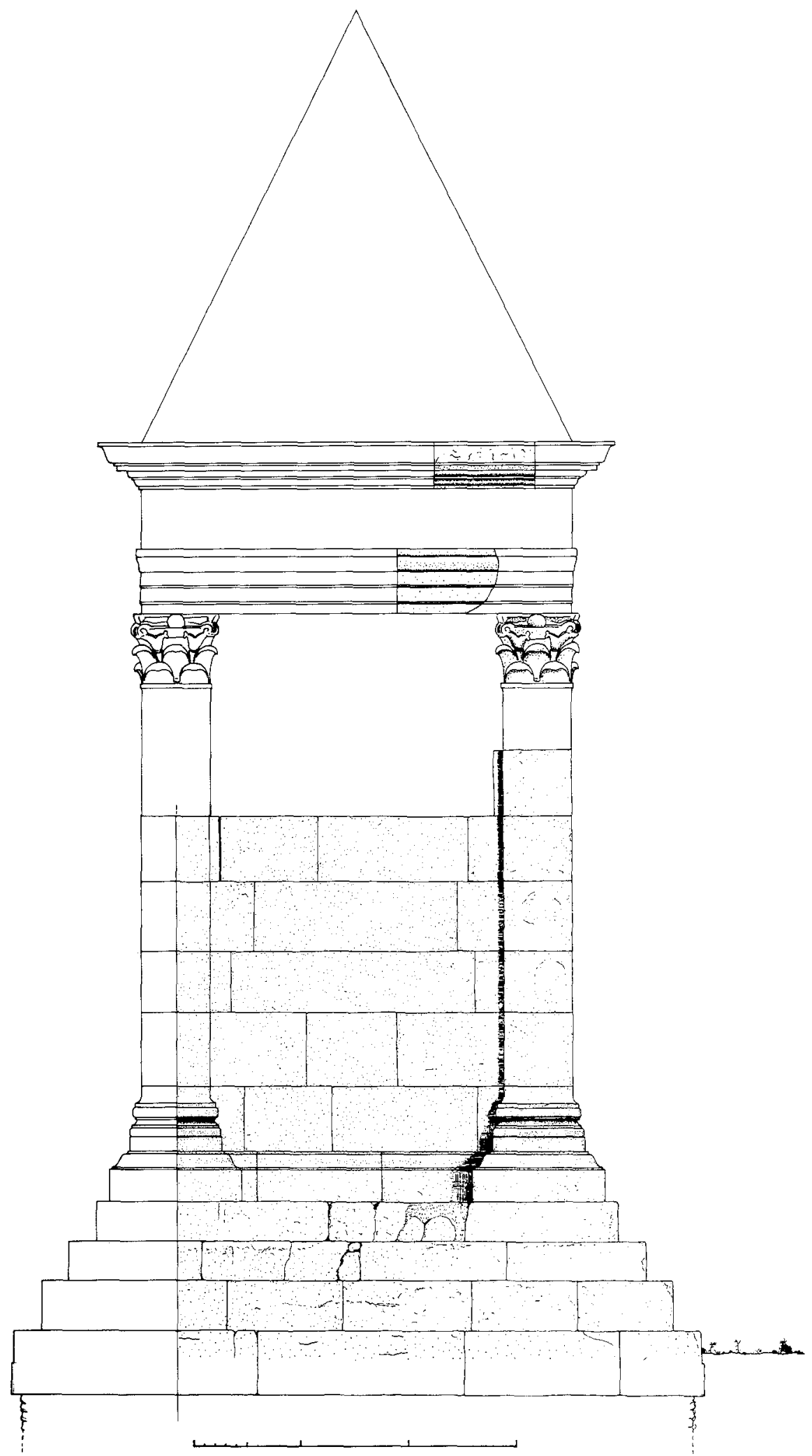

Fig. 21.--Propuesta de reconstrucción del monumento de Villajoyosa. Cara meridional. 


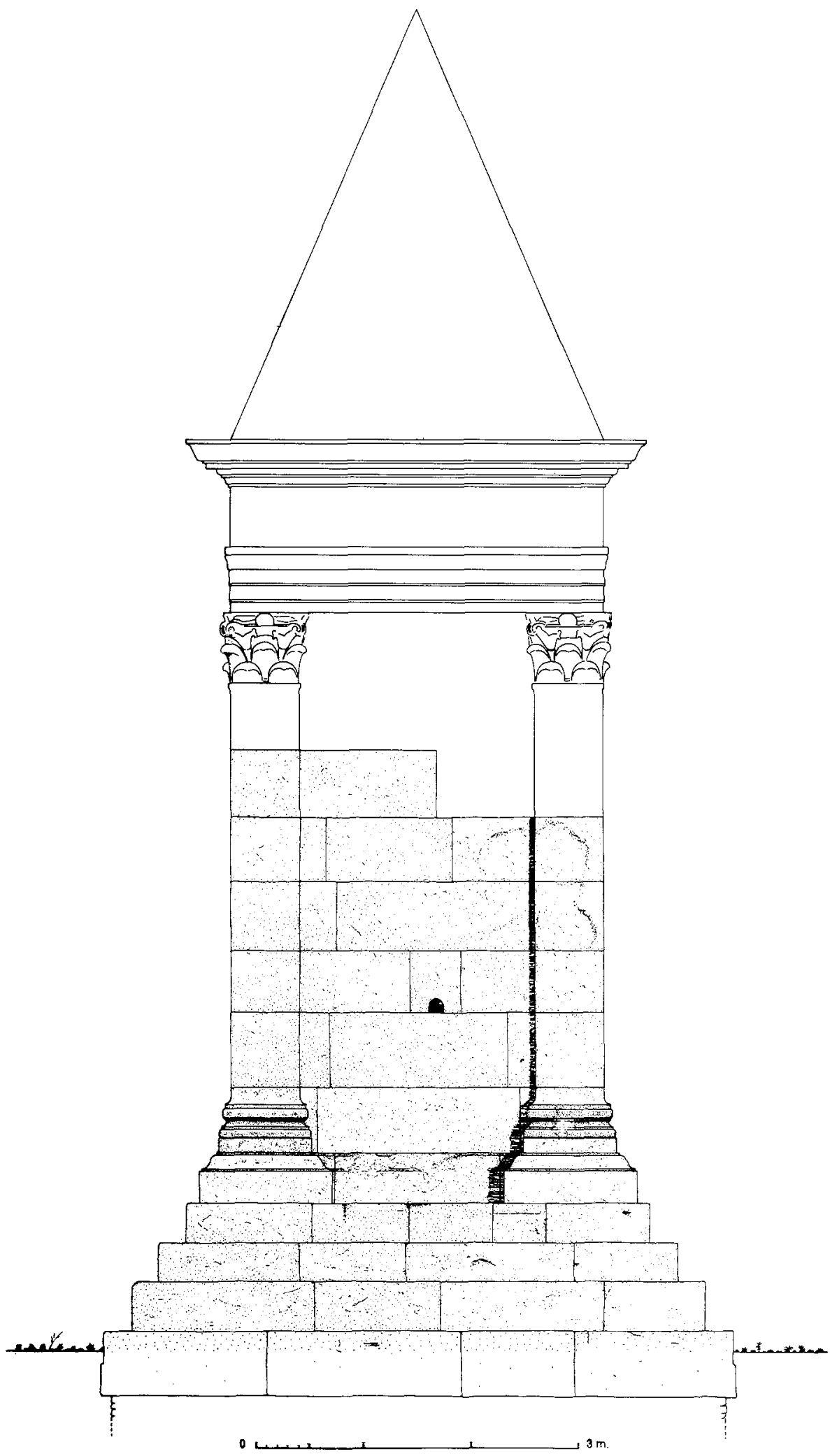

Fig. 22.-Propuesta de reconstrucción del monumento de Villajoyosa. Cara oriental. 


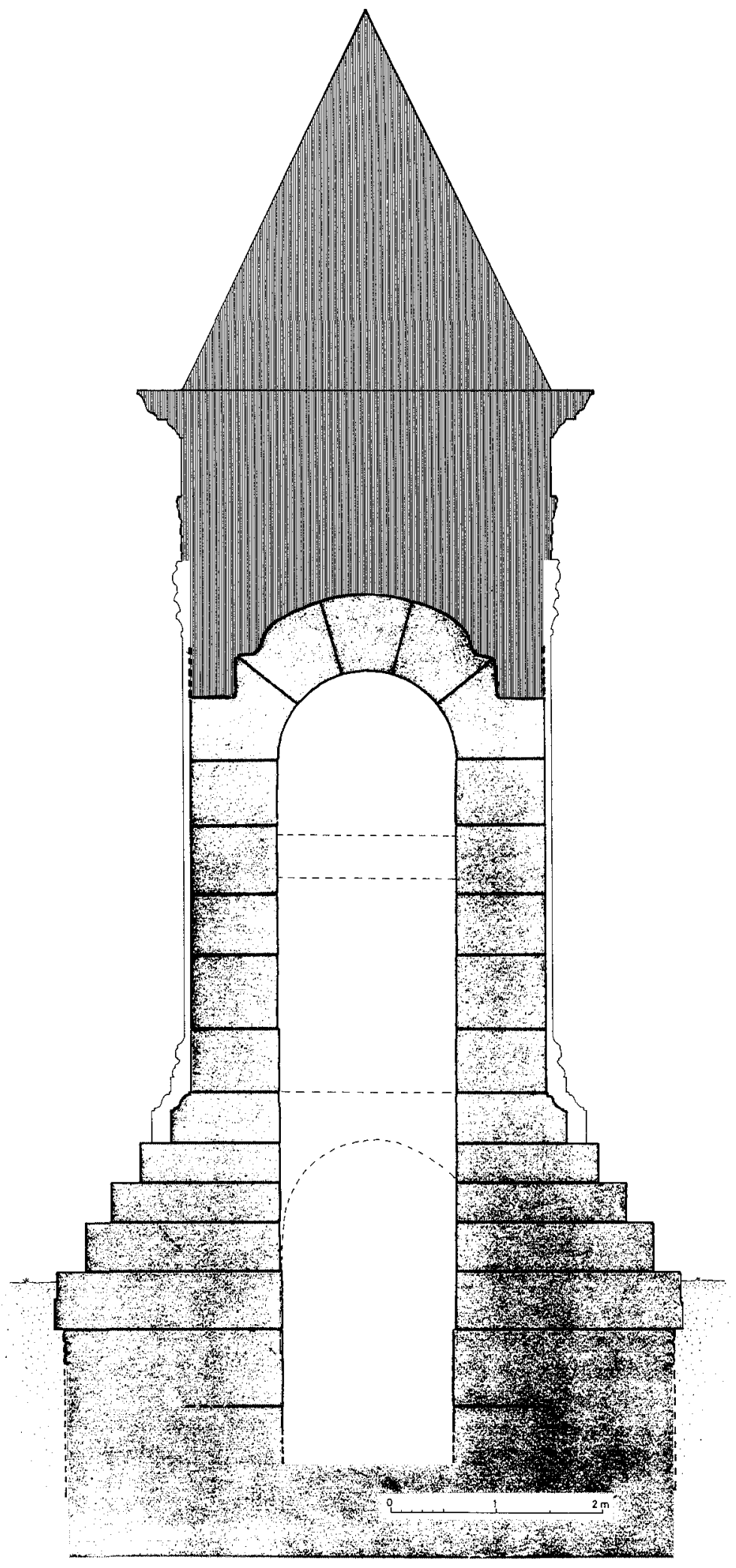

Fig. 23.-Sección del monumento de Villajoyosa (en rayado vertical las partes reconstruidas). 


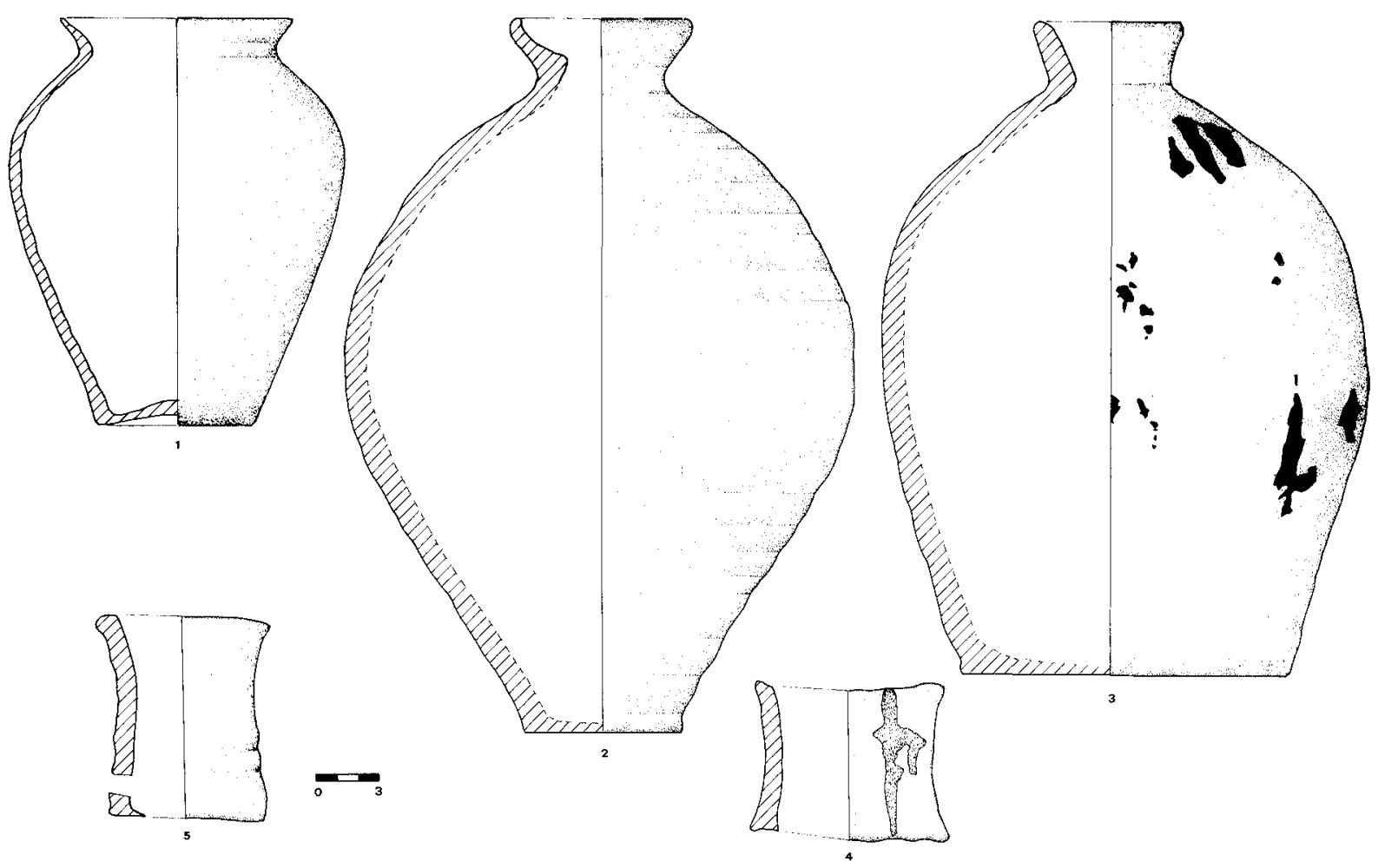

Fig. 24.—Cerámica encontrada en el monumento de Villajoyosa y conservada en el Museo Etnográfico de esta ciudad.

den corintio, que remataban sendas pilastras estriadas. Presentan dos hojas en la ima folia y tres en la secunda folia; entre ellas surgen los caulículos -completamente rectos y casi carentes de boquilla- que sólo llegan hasta la parte superior de la segunda hilera de hojas. De los caulículos arrancan los cálices, que se abren para dar paso a las volutas y a las hélices, de mayores dimensiones aquéllas que éstas. Sobre la hoja central existe una palmeta que se une con las hojas internas de los cálices, y sobre el labio del cálato, de muy poca altura, un ábaco moldurado con una palmeta en su centro. Las hojas, tanto de las coronas como del cáliz, y en general todos sus elementos, se recortan nítidamente sobre el fondo.

Tratar de situar este capitel, conocido tan sólo por un dibujo de tamaño reducido, en la evolución cronológica y estilística del capitel corintio romano es bastante difícil, ya que no sabemos hasta qué punto los detalles del dibujo se corresponden con los de la realidad. No obstante, y suponiendo que las diferencias no fueran demasiado acusadas, pues por regla general los dibujos de Laborde suelen ser poco fantasiosos, podrían destacarse como principales características las siguientes:

1. Las hojas se recortan nítidamente sobre el fondo, pero aparecen bien realizadas, con sus foliolos claramente delimitados a ambos lados del nervio central, con bastante relieve y claroscuro.

2. Los caulículos son completamente rectos y carecen de boquilla.

3. La altura de la corona es bastante mayor que la de la parte superior del capitel.

4. Sobre la hoja central existe una palmeta en relieve.

Todos estos rasgos permiten relacionar el capitel con los fabricados en época de Trajano y sobre todo de Adriano, especialmente con los del vestíbulo del Pantheon de Roma, a los que se asemeja en el fino recorte de las hojas ante el fondo, en la planitud, pese al indudable relieve, de las grandes hojas, en la verticalidad del caulículo con respecto a la hoja-inferior, y en la reducción de tamaño de las hélices con respecto a las volutas. Son los ras- 
gos característicos del corintio del momento (HEILMEYER, 1970, 159 ss., láms. 54 y 55; PENSABENE, 1972, 297 ss., 225 ss., láms. 82 y 83), aunque en nuestro capitel encontramos otros propios de un momento anterior y de una escuela provincial: la existencia de una palmeta que oculta el tallo de la flor del ábaco, muy frecuente en capiteles del siglo I d. C., como los del Arco de los Sergii en Pola, de época de Augusto (HEILMEYER, 1970, 116, lám. 42,1), los del «Templo del altar redondo») de Ostia (HEILMEYER, 1970, 128, lám. 45,2 ) o los del Capitolio de Brescia (HEILMEYER, 1970, 132, lám. 46,2); también la inexistencia de nervios secundarios en las hojas y la falta de boquilla en el caulículo, aunque este último rasgo podría deberse a un efecto del dibujo.

Pese a todas estas anomalías - que por otra parte no hacen sino reflejar el diverso ambiente cultural y técnico que existía entre la capital del Imperio y un apartado lugar de provincias-, la coincidencia de rasgos básicos nos hace suponer que el capitel debe encuadrarse dentro de los realizados en la primera mitad del siglo II d. C. Queda claro, a nuestro entender, que quien los labró conocía ya las innovaciones producidas en Roma en la época de Trajano y Adriano, aunque las traduzca a un lenguaje artístico arcaizante y provincial.

Más difícil aún es estudiar los capiteles correspondientes al monumento de Villajoyosa, aunque para ello contamos con los dibujos de Lumiares y de Laborde y con una pieza conservada en las proximidades de la torre. El Conde de Lumiares dice que él vio dos capiteles, «uno encajado en la pared de la casa contigua y otro al pie de la noria, como representa el número 341» (LUMIARES, sf, 101, núm. 341). Dibuja, de manera muy esquemática, un capitel corintio sin terminar de labrar. Pocos años más tarde, Laborde reproduce otro capitel (LABORDE, 1806, lám. CXXXV), que estaba «compris (...) dans un mur auprès de la porte d'entrée de la basse-cour». Parece, pues, que corresponde al primero de los citados por Lumiares, precisamente el que éste no dibujó. El propio Laborde indica que está solamente esbozado, listo para recibir los detalles de la escultura («il n'est absolument qu'ebauché, et prêt à recevoir les détails de la sculpture»). Se trata de un capitel idéntico en casi todos sus detalles, excepto en el grado de acabado, al anteriormente citado de Daimuz; las únicas diferencias estriban en que en el de Villajoyosa los caulículos sí tienen boquilla y no existe en cambio mo- tivo decorativo alguno sobre la hoja central de la corona. La semejanza es tan grande que parece lícito pensar que o bien este capitel ha salido de la misma mano que el anterior o bien se ha dibujado teniendo a la vista el de Daimuz. Si los rasgos principales del dibujo fueran ciertos, nos encontraríamos ante un ejemplar muy próximo al de Daimuz y cabría aplicarles casi todo lo que de éste se dijo en su momento. No obstante, los detalles arcaizantes han desaparecido y el ábaco bastante más grueso, las presencia de boquilla en los caulículos y la inexistencia de palmeta sobre la hoja central de la secunda folia, permitirían datarlo en un momento más avanzado del siglo II d. C.

Por suerte, el dibujo de Laborde puede ser contrastado con un capitel que aún hoy se conserva en las proximidades del monumento (figs. 17 y 18), con huellas de haber estado encastrado en una pared, por lo que podría corresponder al primero de los citados por Lumiares. Se trata de un capitel de esquina corintio inacabado, con dos hojas de penca en la ima folia y tres en la secunda, entre las cuales arrancan los caulículos; de éstos nacen robustos cálices cuyas hojas interiores, muy desarrolladas, ocupan el lugar de las hélices, que aparecen como atrofiadas en forma de minúsculos abultamientos en los extremos de los cálices. El ábaco, de tosca molduración, presenta en el lugar de la flor un simple óvalo liso. Es por tanto un capitel relacionable con los dibujados por Lumiares y Laborde, sobre todo con el de este último. La estructura general es la misma, y resulta particularmente significativa la representación de la hoja interior de los cálices, cuya prolongación ocupa en buena parte el lugar que debía corresponder a las hélices.

Los diversos autores hacen referencia a que el capitel de Villajoyosa se encuentra inacabado, pero ello no es del todo cierto. Se trata en realidad de un capitel de pencas que corresponde al tipo que Heilmeyer $(1970,140 \mathrm{ss}$.) denomina Bossierte Kapitelle, es decir, capiteles esbozados, que no constituyen simples capiteles corintios inacabados, sino que conforman una variante de los mismos que, en forma muy minoritaria, se encuentra ya en época helenística y perdurará durante largo tiempo. Pensabene, en su estudio sobre los capiteles de Ostia (1973, 239 ss.), data el conjunto ostiense entre los siglos I y IV d. C. Se trata de capiteles en los que todas sus partes han quedado esbozadas, a excepción, en los más antiguos, de las volutas y de las hélices, que muestran sus roscas ya labradas. Lo 
mismo ocurre con la flor del ábaco, que en los primeros ejemplares se conserva como un grueso resalte pétreo, y con el ábaco, que mantiene sus elementos bien diferenciados. Todo ello se compadece muy bien con los caracteres del capitel de Villajoyosa y creemos, por tanto, que puede identificarse como un capitel de este tipo datable, según la serie de Pensabene para Ostia, a lo largo del siglo II d. C., quizás hacia los años centrales del mismo. En España existen varios capiteles de esta clase; $c f$. la serie de «capiteles corintios de hojas lisas» de los capiteles de Mérida y, especialmente, un capitel de pilastra fechado en los siglos II-III d. C. (BARRERA, 1984, 58, n. 87; cf. también DÍAZ MARTOS, 1984, passim).

\subsection{Basas y molduras}

Todas las basas de los monumentos de Daimuz y Villajoyosa (fig. 25) son de tipo ático, aunque difieren en que las del segundo llevan plinto y las del primero carecen de él. Hace algunos años, Wegner (1966) dedicó un estudio a las basas decoradas de la ciudad de Roma, llegando a la conclusión (1966, 10 ss.) de que las de tipo ático son muy frecuentes en la Roma tardorrepublicana, aunque por regla general carecen de plinto, y se hacen extremadamente raras entre Augusto y Adriano, hasta tal punto que en la Roma de esta época sólo puede citar como ejemplo el pórtico de los Dii Consentes. En cambio, a partir de Adriano, y sobre todo de Antonino Pío, este tipo de basas - ahora sobre plinto - se harán muy abundantes (vid. los ejemplos aducidos por Wegner, loc. cit.), en dura competencia con las de tipo compuesto, excepto en Oriente, donde siempre ejercieron la primacía $a b-$ soluta.

Falta aún en Hispania un estudio detallado sobre las basas de columna romanas y su evolución, y difícilmente podríamos aplicar las conclusiones de Wegner, que se refieren a basas decoradas de la ciudad de Roma. Parece, no obstante, que en la mayoría de los monumentos se empleó la basa ática en sus diversas modalidades. Según A. Jiménez $(1975,290)$, las basas sin plinto alcanzan su máximo apogeo entre los años 100 a. C., y 50 d. C., para desaparecer casi por completo a continuación. Si ello fuera cierto, los monumentos de Daimuz y Villajoyosa deberían corresponder a diferentes momentos, lo que, sin embargo, parecen desmentir algunas de sus restantes características. Hay que señalar, asimismo, el estrecho paralelismo que presentan las basas de nuestros monumentos con algunas claramente datadas en el siglo II d. C., como las del templo de Antonino y Faustina en Roma (HIRSCH, 1925, 137, fig. 322), las del templo de la Concordia en Dugga, de época de Adriano (FERCHIOU, 1975, lám. 7) o las del arco de Marco Aurelio y Lucio Vero en Trípoli (AURIGEMMA, sf, láms. xxi-xxii). Aún podría citarse la estrecha semejanza entre las molduras de remate de nuestros podios y las del zócalo de las puertas de Adriano en Atenas y Adalia, entre otras (LANCKORONSKI, 1890, láms. viiviii).

Es muy difícil, por tanto, tomar las basas de los monumentos de Daimuz y Villajoyosa como elementos de datación; parece, no obstante, que sus más estrechos paralelos se encuentran en monumentos de mediados del siglo II d. C., lo que, unido a la fecha que proporcionan los capiteles, permite suponer que ambos edificios se construyeron en este momento.

El arquitrabe y la cornisa de la tumba de Villajoyosa - la única que los conserva- responden a modelos muy extendidos en el mundo romano y son en sí mismos de difícil datación (cf. ASHBY, 1904, passim).

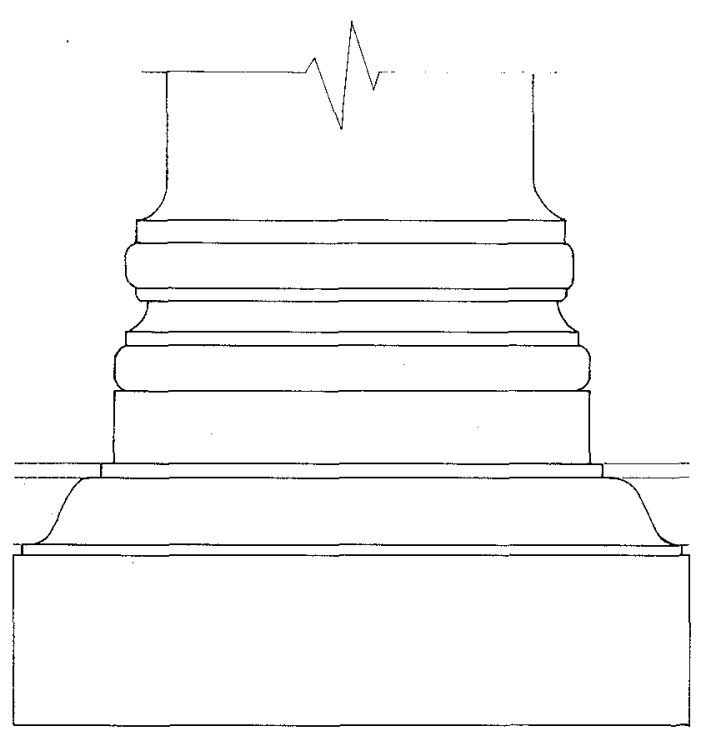

Fig. 25.-Basa del monumento de Villajoyosa. 


\section{LOS MONUMENTOS DE DAIMUZ Y VILLAJOYOSA EN EL CONJUNTO DE LOS SEPULCROS TURRIFORMES ROMANOS}

\subsection{E\ tipo arquitectónico; historia de la investigación}

Los monumentos funerarios romanos con varios pisos superpuestos, entre los que se incluyen los que aquí estamos tratando, han generado una copiosa bibliografía arqueológica, ya que su amplia difusión, su larga perduración, y la diversidad de tipos existentes, dificultan considerablemente cualquier intento de ordenación. El primer ensayo moderno de sistematización es obra de F. Matz $(1928,266$ ss.), quien identificó una serie de elementos comunes a todos ellos: zócalo macizo en la parte inferior, cuerpo principal de diversas formas y remate cónico y piramidal que constituye el elemento más característico. Este autor se enfrentó ya con el problema de buscar el punto de relación entre los monumentos cuyo cuerpo principal tiene forma de templo, los que recuerdan un arco tetrápylon y los que presentan unas paredes completamente cerradas al exterior, sean éstas lisas o decoradas mediante pilastras en relieve. Cree que todos ellos se encuentran unidos por la idea básica de elevar al difunto sobre el mundo cotidiano; se trataría, en cierto modo, de una heroización, muy del gusto oriental, simbolizada en el predominio de la verticalidad del monumento.

La idea original de Matz fue retomada poco tiempo después por $\mathrm{H}$. Kähler (1934, 145 ss.), quien al estudiar los monumentos en forma de pilar (Pfeilergrabmäler) del Rin, se plantea el problema de forma general e indica que muy posiblemente el origen último de todos estos monumentos se encuentre en las estelas funerarias con relieves, cuya imparable tendencia hacia una mayor monumentalidad y riqueza ornamental las habrían hecho evolucionar hacia los monumentos con un templete en forma de edicula en su cuerpo principal, por una parte, y hacia los monumentos en forma de pilar con una riquísima decoración ornamental, como los ya tardíos de Igel, por otra. En este trabajo de Kähler se citan algunos monumentos españoles, como los de Vilablareix y Lloret de Mar, que se incluyen en la categoría de los Nischengrabmäler, esto es, de los monumentos cuyo cuerpo superior presenta una abertura en forma de nicho, y el de Tarragona, que el autor relaciona con el de Terón de Agrigento y considera un claro ejemplo de fusión de los dos tipos característicos: el de edícula, tal y como puede verse en los monumentos de Sarsinia, y el de tipo pilar. En su trabajo, Kähler pasa revista a buena parte de los mausoleos conocidos en África, Asia y Europa, y plantea ya el problea básico: cómo pueden relacionarse los dos tipos de edificios: el abierto y el cerrado.

Años más tarde, será Cid Priego (1949, 91 ss.) quien vuelva a tratar sobre el origen y la evolución de este tipo de construcciones funerarias. Para él, su origen se encuentra en los meghazil fenicios, a los que los griegos añadirían pronto un podium escalonado y un peristilo o seudoperistilo como cuerpo principal, y cuyo máximo representante sería el Mausoleo de Halicarnaso; junto à esta versión, que podríamos denominar «moderna», se mantendría siempre otra más tradicional, compuesta por basamento, prisma o prismas superpuestos y remate piramidal (ídem, 116). En este trabajo, y en otros anteriores y posteriores, Cid Priego dio a conocer $(1949,1950)$ los distintos sepulcros turriformes hispanos, que desde entonces se incorporan a la bibliografía arqueológica. No obstante, como en la mayor parte de los casos se limita a recoger noticias antiguas y las ilustraciones se reducen a croquis muy esquemáticos, el conocimiento de la mayor parte de estos monumentos seguirá siendo aún hoy bastante incompleto.

En 1959 se inicia una nueva etapa con la edición de la obra L'architettura romana, de L. Crema, dentro de la serie Enciclopedia Classica que dirigía P. E. Arias (CREMA, 1959). Aunque se trata de una obra de tipo general, sus observaciones sobre los monumentos funerarios se convertirán en punto de partida para los trabajos posteriores. $\mathrm{Pa}$ ra Crema, los monumentos turriformes - término que englobaría a todos aquellos con varios pisos superpuestos- tendrían su origen en los del tipo del Mausoleo de Halicarnaso, y contarían con un cuerpo principal en forma de templete abierto, de donde derivarán posteriormente tanto aquellos cuya abertura se reduce a una de las fachadas (monumentos «a edícula») como aquellos otros completamente cerrados y decorados con pilastras o semicolumnas adosadas (monumentos «a pila»). Entre los primeros se contarían los de Sarsinia, rematados por una pirámide de lados curvos -y también el de Poblicius en Colonia, descubierto tras la publicación del libro de Crema-y entre los segun- 
dos el de Terón en Agrigento. Estos dos tipos se mantendrán a lo largo de toda la historia romana. Crema reserva el calificativo de monumentos «a torre» para los de proporciones más alargadas, como el de Maktar o el de Kassrine, en el Norte de África, y datados al menos en el siglo II d. C.; el segundo de ellos presenta la novedad de un tercer piso al que se ha transferido la edícula. Será este tipo de monumentos africanos «a torre» el que desde el Norte de África se extenderá hacia España, dando lugar a edificios como la Torre de los Escipiones o la de Vilablareix.

Pocos años más tarde, G. Mansuelli sistematizó en el volumen V de la Enciclopedia dell'Arte Antica $(1963,170$ ss.) los distintos tipos de monumentos funerarios. Cuatro de ellos, los denominados «a podio», «a edicula cuspidale», «a torre e a guglia» y «ad altare» nos interesan especialmente. Los dos primeros formarían en realidad un solo grupo, ya que el segundo no sería sino una variante del anterior, con el cuerpo superior total o parcialmente abierto (Sarsinia, Via Nocera en Pompeya, Hadra, Termessos, etc.), en tanto aquél lo muestra cerrado, decorado o no con pilastras adosadas y falsas puertas (Tumba de Terón, de las Guirnaldas, de Bíbulo, etc.). El nombre de monumento «a torre» debería reservarse para los de Siria, con cámaras interiores superpuestas que no se reflejan en el exterior, aunque Mansuelli cree posible, por extensión, designar con este nombre a otros monumentos en los que la dimensión vertical sea la predominante y cuya plasmación más exagerada serán los «a guglia» centroeuropeos de finales de la Edad Antigua. En cuanto a su origen, Mansuelli lo cree helenístico, pero frente a otros autores que postulaban un origen oriental, aduce que los más antiguos se encuentran en Occidente, y cita entre ellos los monumentos de Terón en Agrigento y de Thuga en África. Por último, incluye entre los monumentos «ad altare» algunos que en realidad son turriformes, como el de las Guirnaldas de Pompeya, y reconoce que, en ocasiones es difícil diferenciarlos de los de podio, ya que muy pronto se revisten de formas arquitectónicas: zócalo escalonado, pilastras en las esquinas, friso dórico, etc., y, salvo en la multiplicidad de pisos, ambos tipos son muy semejantes.

Mucho tiempo habrá de pasar antes de que otro autor, H. Gabelmann (1977, 105 ss.; 1979) se replantee el problema de la distribución geográfica y cronológica de estos monumentos (figs. 26 y 27).
Para él, el concepto «sepulcro turriforme» (Turmartiges Grabbau) debe incluir a todos aquellos cuya forma básica comprenda un zócalo escalonado (Stufenunterbau), un primer piso cuadrado o rectangular, adornado o no con pilastras, y un segundo piso que puede adoptar muy diversas formas: frente columnado, edícula o baldaquino. Todas ellas derivarían, en último término, del Mausoleo de Halicarnaso, por lo que cree que podría hablarse incluso de una forma básica de tipo «Mausoleo». Del tipo I, de frente columnado con frontón (Säulenfronttypus mit Giebeln) se deriva un subtipo que sustituye las columnas exentas por otras adosadas (Relieffronttypus).

La síntesis más reciente, la de W. Kovacsovics (1983), postula el empleo del término «turmartige Gräber», que podría traducirse como «sepulcros turriformes», con lo que entroncaríamos con la denominación característica en la bibliografía hispana. Distingue cuatro tipos: tholos, edícula, túmulo y un cuarto que agruparía formas de difícil inclusión en las anteriores. El que más nos interesa para nuestro trabajo es el segundo tipo, aunque en éste sólo deberían incluirse «Grabbauten (...) die nun in ihrem Obergeschoss einen kleinen peripteralen Tempel aufweisen, bei dem am mehreren Fronten Abkürzungen oder Blendarchitekturen gegeben sind (...)». Las tumbas en forma de edícula serán, pues, todas aquellas cuyo cuerpo principal se encuentre formado por una construcción que recuerde la de los templos, de cualquier tipo que éste sea, desde los más simples in antis hasta los perípteros más complejos. Estudia numerosos templos para concluir que se trata de una realización característicamente tardorrepublicana, visible ya en tumbas italianas de la primera mitad del siglo I a. C., como la de las Guirnaldas de Pompeya. Desde aquí se extenderá hacia el Norte de Italia, la Galia, el Rin, Asia Menor y el Norte de África, en su mayor parte con cubierta en forma de pirámide, y con una perduración cronológica que en Occidente alcanza los años finales del siglo II d. C.

Dentro de este grupo de tumbas de edícula puede identificarse otro, mucho menos frecuente, que el autor designa como «geschlossene Aedicula» (1983, 114 ss.), esto es, como «edícula cerrada», aparente contrasentido que trata de indicar que lo que en el grupo anterior estaba abierto hacia el exterior, ahora se encuentra celosamente oculto, y que por todas partes la tumba ofrece al espectador tan sólo un muro corrido. No obstante, las paredes 
pueden estar compartimentadas por pilastras -sólo en las esquinas o a lo largo de las fachadas - y, en ocasiones, muestran uno o varios entrantes para las estatuas o los relieves de los difuntos. En este grupo se incluyen monumentos como la llamada tumba de Pompeyo Magno en Alba Longa, la de Terón en Agrigento (fig. 28), los sepulcros de los Veienti y M. Virgilius Eurysaces en Roma, entre otros, y, especialmente interesante para lo que ahora nos interesa, la Torre de los Escipiones de Tarragona. Ya Kovacsovics llama la atención sobre un grupo de monumentos hispanos que se salen de lo normal («cuya composición exterior se aparta del esquema acostumbrado», son sus palabras textuales), entre los que incluye los de Cartagena, Villajoyosa, Vilablareix y Manresa y cuya cronología establece entre los siglos II y III d. C. (5) (KOVACSOVICS, 1983, 148, n. 328). No deja de resultar significativo que este autor, tras pasar revista a un buen número de monumentos de ese tipo, agrupe a varios de los hispanos dentro de un conjunto de características especiales.

Con anterioridad a la obra de Kovacsovics, los sepulcros turriformes hispanos apenas si han sido citados en la bibliografía correspondiente. Ello se debe a la casi absoluta carencia de publicaciones sobre el tema, pues para estudiar muchos de estos monumentos es aún necesario recurrir a los grabados de Laborde, de comienzos del siglo XIX. Ya en el siglo XX, Puig i Cadalfach realizó una síntesis de los monumentos correspondientes a la mitad oriental de la Península Ibérica $(1934,117$ ss.), pero se trata de una publicación difícilmente asequible, por lo que la mayor parte de los autores que han tratado el tema se han basado en los artículos ya citados de Cid Priego $(1949,1950,1951)$, cuya principal aportación fue de orden teórico, ya que basó sus descripciones en los datos de Laborde y Puig, sin reproducir sus dibujos ni realizar otros nuevos.

Tras los trabajos de Cid Priego, los estudios sobre estos monumentos se redujeron al de la Torre de los Escipiones (Hauschild, Mariner y Niemeyer, 1966; Gamer, 1982) y a la publicación de algunas notas sueltas sobre un grupo de sepulcros turrifor-

(5) «Der Kenotaph von Tarragona ist nicht das einzige Denkmal in Spanien, bei dem die Aussengliederung von dem gebräuchlichen Gestaltungsschema abweicht, es leitet eine ganze Reihe von mehrstöckigen Grabbauten ein, die grösstenteils keine Blendordnung besitzen und nur vereinzelt von Eckpilastern eingefasst sind» (KOVACSOVICS, 1983, 124).
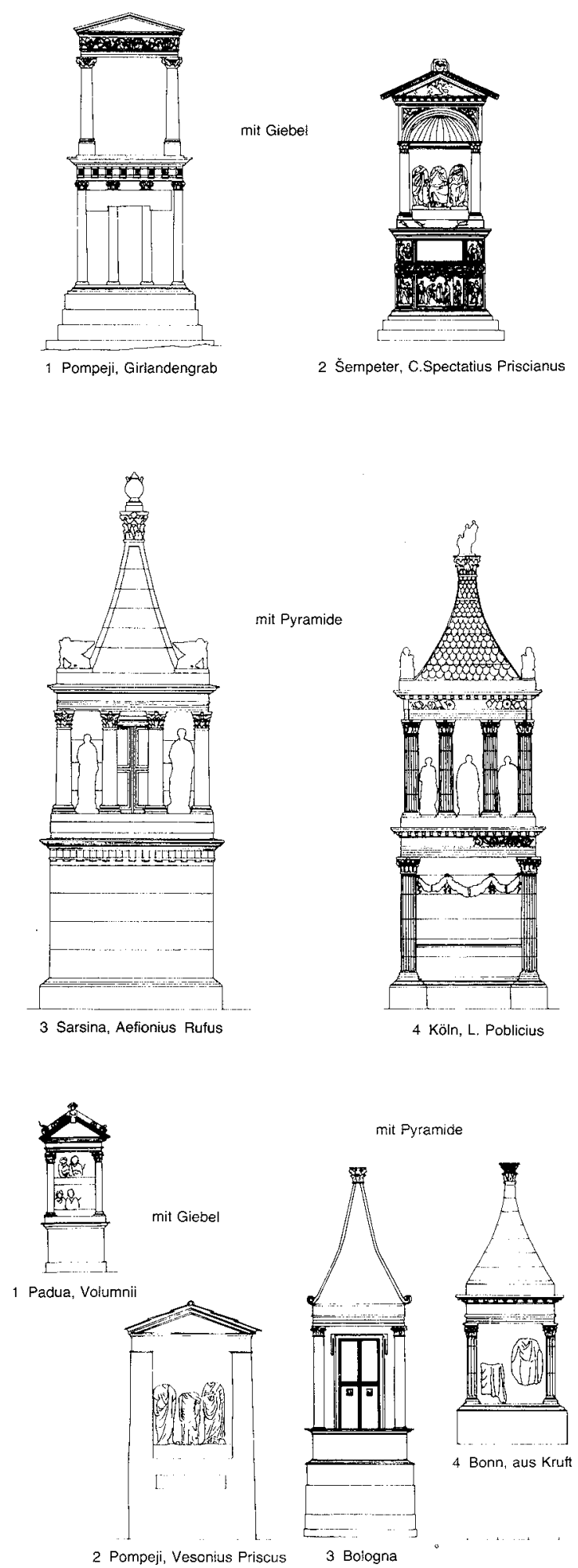

Fig. 26.-Monumentos turriformes europeos, según Gabelmann (1979). 

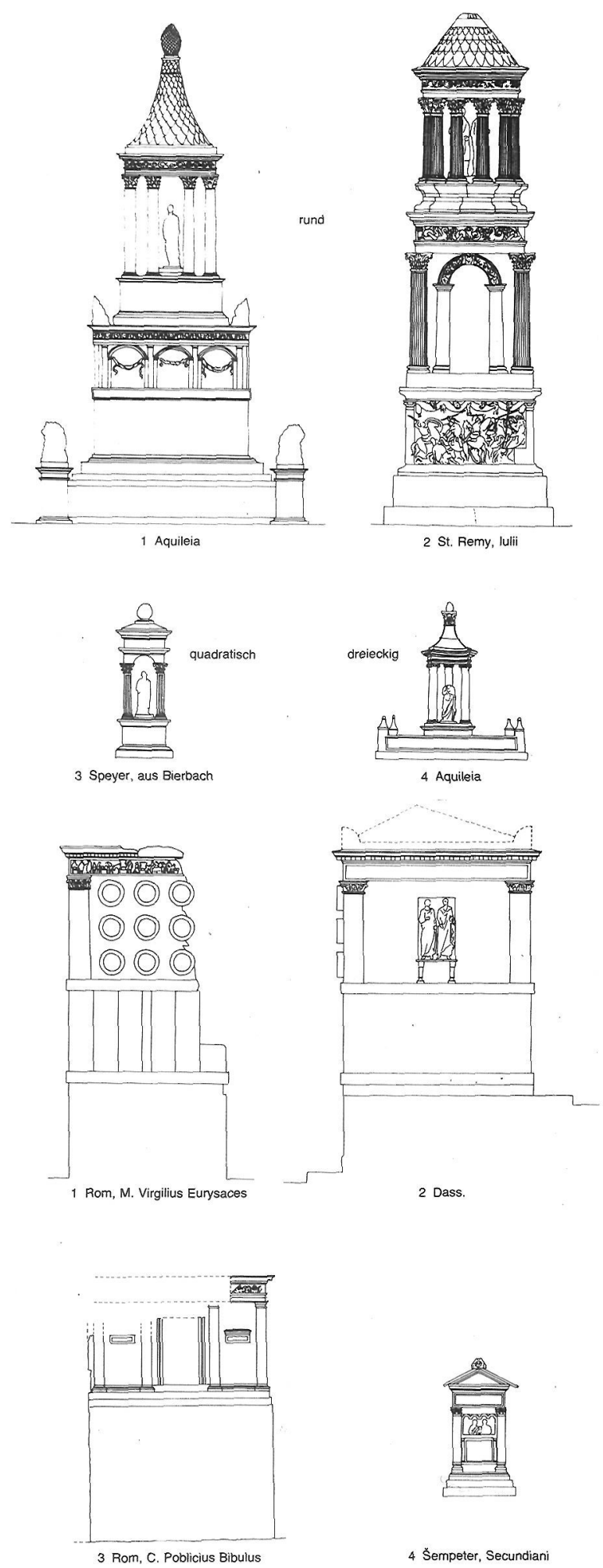

Fig. 27.-Monumentos turriformes europeos, según Gabelmann (1979). mes de la Andalucía occidental (JIMÉNEZ, 1975, 869 ss.; RODRÍGUEZ HIDALGO, 1979-80, 425 ss.), o de monumentos concretos, como los de Sofuentes, del que sólo se conocen algunos relieves y restos de pilastras (FATAS y MARTÍN BUENO, 1977, 232 ss.) y Vildé, muy alejado este último, tipológica y estructuralmente, de nuestros edificios (GARCÍA MERINO, 1977, 45 ss.). Muy recientemente, J. Sanmartí ha realizado un estudio de conjunto sobre los monumentos sepulcrales de la España Oriental $(1984,87 \mathrm{ss}$.) que recoge todo lo publicado sobre cada uno de ellos y constituye un instrumento de trabajo imprescindible. Los monumentos que aquí nos interesan son los que él incluye en los apartados «edículas sobre podio» (Miralpeix, Caspe, Alcover, Torre del Breny, Daimuz, Villajoyosa, Sagunto, Barcelona y Tarragona) y «turriformes» (Torre de los Escipiones, Vilablareix, Lloret de Mar, Aiguaviva, Ampurias, Camprodon, Sofuentes y Cartagena), aunque de todos ellos tan sólo los de Miralpeix, Torre del Breny, Daimuz, Villajoyosa, Sagunto, Torre de los Escipiones, Vilablareix y Lloret de Mar ofrecen elementos suficientes para su utilización como monumentos de referencia.

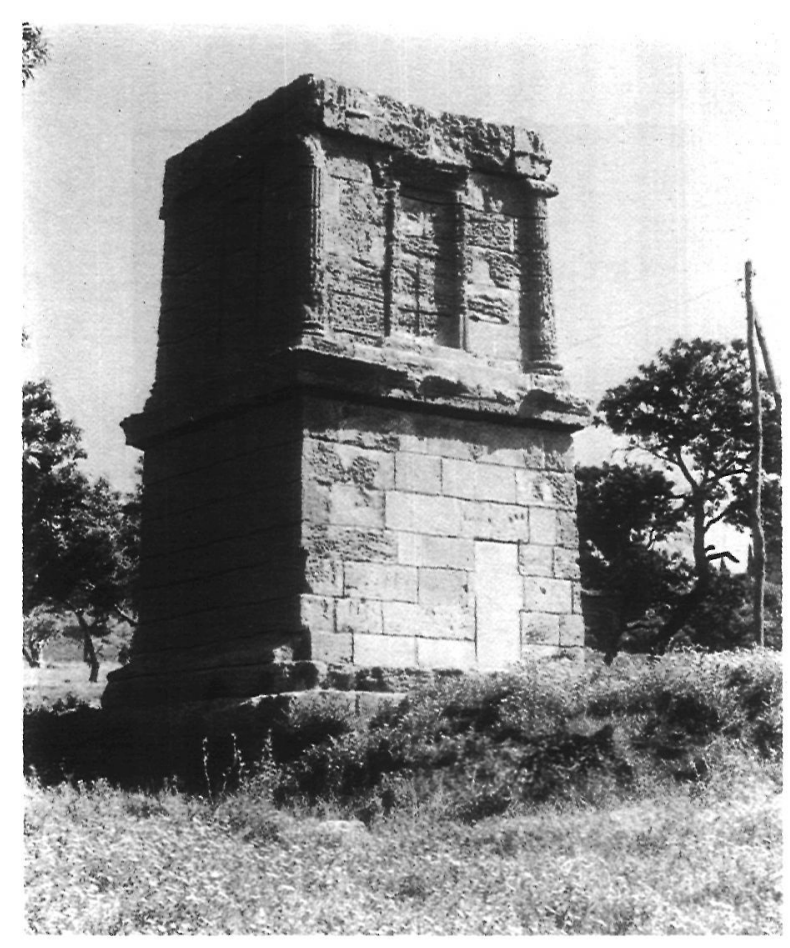

Fig. 28.-«Tumba de Terón» de Agrigento, según Gabelmann (1979). 
Creemos que, para evitar confusiones, estos dos grupos de Sanmartí pueden contemplarse bajo la denominación común de monumentos «turriformes», diferenciando entre los de edícula abierta (Vilablareix, Lloret de Mar, El Cincho y quizás Miralpeix) (6) y los de edícula cerrada (Torres del Breny, de los Escipiones, de Daimuz y de Villajoyosa), en tanto otros monumentos tendrían que incluirse en el grupo cuarto que propone Kovacsovics.

\subsection{El tipo arquitectónico: su distribución geo gráfica y cronológica}

El problema del origen y del encuadramiento cronológico de todos estos monumentos es bastante difícil de resolver. Kovacsovics los considera como algo plenamente romano, desarrollo de una tradición helenística anterior y cuya génesis se reflejaría en algunas pinturas con edícula del segundo estilo pompeyano. Frente a esta visión, que podríamos calificar de autoctonista (KOVACSOVICS, 1983, 76), existen otras que ponen el acento en una incorporación a Roma a través del norte de África y, más concretamente, del mundo púnico (POINSSOT y SALOMONSON, 1963, 57 ss.), re-lacionando el monumento de Terón con otros africanos similares, como la Suma de Kroub o el monumento de Thugga (RAKOB, 1979, 145 ss.). Otros autores, en cambio, les asignan un origen oriental, haciendo ver sus semejanzas con los de la Siria Occidental (WILL, 1949, 258 ss., contradicho por GAWLIKOWSKI, 1970, 21) o, en todo caso, con los del Oriente en general (KOCKEL, 1983, 26 ss.) (7). Las conclusiones a que puede llegarse hoy día son las siguientes:

1. En Oriente, las tumbas de este tipo derivan del Mausoleo de Halicarnaso o, mejor, de monumentos funerarios más sencillos y antiguos, como el de las Nereidas de Xantos, que definen mejor el tipo monumental seguido después e inician la serie de realizaciones en que se inserta el sepulcro de

(6) En este grupo podrían incluirse asimismo edificios de tipo naomorfo, como el de Fabara (BLANCO, 1976, 72 ss.).

(7) En las páginas que siguen centraremos nuestra atención en los monumentos de época romana, incluyendo cuando sea necesario los de época tardohelenística, pero sin entrar en profundidad en los problemas relacionados con el origen último de este tipo monumental, tratado in extenso por los autores ya citados. Cf. también ALMAGRO, 1982, 191 ss., y 1983, 208 ss.
Mausolo; este gigantesco edificio, excepcional por su arquitectura y su decoración escultórica, debió contribuir sin duda, por su fama, a la consolidación y arraigo de este tipo de monumentos. En época posterior, más próxima ya a la de nuestros edificios, los sepulcros turriformes orientales carecen por regla general de podio y de diferenciación exterior en pisos y poseen en cambio en su interior una serie de cámaras superpuestas, con arcosolios y loculi, que los alejan considerablemente de lo que es normal en nuestros monumentos. Los más próximos tipológicamente a éstos son siempre excepciones en el conjunto y, a lo que parece, bastante antiguos. Entre ellos destaca uno de Dana-Sud, en Siria, que sobre zócalo no escalonado muestra un cuerpo principal con pilastras en las esquinas y está rematado por una pirámide, aunque el pórtico añadido y la puerta abierta al exterior le confieren un carácter propiamente oriental (HERMAN, 1964, lám. VII, 2); más parecido es aún uno de Hermel, cerca de Baalbeck, que muestra un zócalo escalonado, un cuerpo inferior decorado con pilastras en los ángulos y relieves en los frentes, y un cuerpo superior con cuatro pilastras en cada una de las caras, rematado todo ello por una pirámide (KRENCKER y ZSCHIETZSCHMANN, 1936, 161 ss., fig. 231; WILL, 1949, 273 ss., fig. 161); este edificio, que fue restaurado completamente por una misión arqueológica francesa en 1931, era macizo y se data - a falta de un estudio moderno de los relieves del cuerpo principal, que podrían precisar más la fecha- en época helenística.

2. En el Norte de África existen sepulcros turriformes de varios tipos, al menos desde comienzos del siglo II a. C. (GSELL, 1901). Entre ellos destacan los monumentos de época púnica de Sabratha, Siga, Thugga y Es Sumáa (El Kroub), estos dos últimos ya de la segunda mitad del siglo II a. C. (RAKOB, 1979, 145 ss.); ambos muestran zócalo escalonado y varios cuerpos, con pilastras adosadas en el primero y edícula en el segundo, y están rematados por sendas pirámides. Bastante antiguos parecen ser asimismo los monumentos de Akbou, con cuerpo cuadrangular sobre podio escalonado con cámara accesible y rematado en pirámide, y Kar Tenacef, también de un solo cuerpo, con pilastras corintias en las esquinas, sobre pódium sin escalonar y coronado, en este caso, con un frontón curvo (GSELL, 1901, núms. 3 y 22); tanto uno como otro parecen datarse en época helenística. A este mismo momento debe corresponder el monumento de Zawani, con alto podium es- 
calonado, cuerpo principal con cámara y pilastras en las esquinas y remate posiblemente piramidal (STUCCHI, 1975, 177, fig. 178). Más tardíos deben ser los monumentos de Leptis Magna y Maktar; el primero muestra alto podium escalonado, un primer cuerpo cerrado con pilastras corintias lisas y un segundo cuerpo también con pilastras en el que se abre una edícula; el segundo, datado en el siglo II d. C., y también con edícula en el piso superior, muestra ya el amplio desarrollo vertical que, por medio de la multiplicación de pisos, será característico de los sepulcros turriformes tardíos del Norte de África (ROMANELLI, 1970, lám. 202, a). Del siglo III, según la datación proporcionada por las inscripciones, es el monumento de Kassrine, punto culminante de esta evolución, que muestra zócalo escalonado, cuerpo inferior liso, cuerpo intermedio con cuatro pilastras corintias a cada lado y cuerpo superior en forma de edícula períptera, rematado todo ello por la correspondiente pirámide. La cámara se encontraba en el primer piso y era accesible a través de una puerta.

3. El monumento europeo más antiguo, el llamado «Tumba de Terón» de Agrigento, corresponde, según la mayoría de los autores que lo han estudiado, al siglo II d. C., y es el precursor en Europa de una serie de edificios que, a lo largo del siglo I a. C. se extenderán por toda Italia y, a continuación, por buena parte de Europa, donde son especialmente abundantes a lo largo del Alto Imperio. En este grupo son predominantes los que muestran una edícula abierta en su piso superior, como algunos monumentos de Pompeya (KOCKEL, 1983, 216 ss.), Roma, del siglo I a. C. (KOVACSOVICS, 1983, 73 ss.) y Sarsinia (AURIGEMMA, 1963, 56 ss.), el de Colonia, algo más tardío (PRECHT, 1979), o los numerosos ejemplos recogidos por Kovacsovics $(1983,76$ ss.). Sin embargo, el conjunto que más nos interesa en este momento, porque en él se integran nuestros monumentos, es el que este mismo autor denomina «de edícula cerrada» (1983, 114 ss.), que incluye una amplia serie de monumentos de dos o tres cuerpos.

Encabeza este grupo la tantas veces aludida «Tumba de Terón», de Agrigento, del siglo II a. C., formada por un zócalo ligeramente saliente, un podio moldurado por arriba y por abajo y un cuerpo superior con falsas columnas en las esquinas (MARCONI, 1929, 124 ss.). Los pisos inferiores de la «Tumba de las Guirnaldas» de Pompeya (GABELMANN, 1979, fig. 44,1; KOCKEL, 1983,
132 ss., figs. 22-26), formados por un zócalo escalonado y un primer cuerpo prismático con pilastras corintias adosadas que sostienen un friso dórico, se encuentran también en la línea de nuestros monumentos, aunque se haya propuesto recientemente (Kockel) que su tercer piso sea una edícula abierta. Su datación, en la primera mitad del siglo I a. C., lo convierte en el eslabón entre la «Tumba de Terón» y el relativamente amplio grupo de monumentos ya con toda certeza de «edícula cerrada» de la época de Augusto. Entre ellos se cuentan la llamada «Tumba de Pompeyo Magno» de Albano, reconstruida hoy como un edificio con zócalo y dos cuerpos superiores adornados por pilastras (KOVACSOVICS, 1983, 115, fig. 25), y el monumento de $M$. Vergilius Eurysaces, de tres cuerpos: un alto podium liso, un primer cuerpo con pilastras sin acanalar en los ángulos y un segundo con pilastras corintias en las esquinas; en la cara principal se encontraba el relieve con la efigie de los difuntos y la inscripción (KOVACSOVICS, 1983, 117, fig. 27; ROSETTO, 1973, lám. 46). Algo más antiguo parece ser el monumento de $C$. Poblicius Bibulus, datado recientemente en época de Sila, que sobre alto podio prismático con inscripción muestra al menos en uno de sus frentes pilastras dóricas adosadas con una falsa puerta entre las dos centrales, aunque de todos modos las dificultades de reconstrucción que plantea este monumento son muy numerosas (KOVACSOVICS, 1983, 81, fig. 15; GABELMANN, 1979, fig.44,3). A la época de Augusto corresponde también el monumento de Calvius Turpius en Lyon, con tres cuerpos: un podio liso y de no mucha altura, un primer cuerpo con pilastras jónicas en las esquinas y un segundo del que sólo se conserva lo suficiente para apreciar que existía un mayor número de pilastras por cada cara, aunque ignoramos si se resolvía en forma de edícula o de otra manera (KOVACSOVICS, 1983, 89 ss., fig. 17). Más tardío parece ser en cambio el llamado «Pilone» de Albenga, de tres cuerpos con edícula en el superior, datado por Lamboglia (1961, 118 ss.) en el siglo II d. C.

Los sepulcros hispanos que pueden incluirse en este grupo son, además de los de Daimuz y Villajoyosa, la «Torre de los Escipiones» de Tarragona y la «Torre del Breny» en Barcelona, ambos recogidos ya por Kovacsovics. El primero muestra sobre un zócalo liso dos cuerpos diferenciados por molduras; el inferior con dos figuras de Atis, en relieve sobre pedestales, y el superior con tres nichos deli- 
mitados por pilastras y arcos ligeramente en relieve, en otras tantas caras; en la central se conservan aún en su interior restos de una pareja en relieve. La datación de este monumento, para el que Cid Priego propuso en su día el siglo II d. C. (1948, 169), ha sido establecida recientemente en la primera mitad del siglo anterior (HAUSCHILD-MARINER-NIEMEYER, 1966, 186). «La Torre del Breny» carecía al parecer, como la de Villajoyosa, de edícula o nicho de cualquier tipo (CID PRIEGO, 1950, 21 ss.; SANMARTÍ, 1984, 112 ss.) No citados por Kovacsovics, pero incluibles también en este grupo son los monumentos de Vilablareix, con una amplia edícula en su segundo cuerpo (SANMARTÍ, 1984, 82 ss.), y de Basilippo (RODRÍGUEZ HIDALGO, 1979-80, 425 ss.), de tres cuerpos y con edícula flanqueada por pilastras adosadas.

Está aún por determinar el grado de influencia que en el desarrollo de estos edificios hispanos pudieron tener los monumentos turriformes indígenas de época ibérica, que sólo han comenzado a valorarse recientemente, tras los estudios de M. Almagro (1982, 198 ss.; 1983, 263 ss.); este autor llega incluso a sugerir un posible origen hispano para los monumentos turriformes romanos $(1983,214$, n. 7). No creemos que en el estado actual de nuestros conocimientos pueda llegarse a precisar tanto, pero lo que sí parece evidente es la existencia de una tradición ibérica que adquiere renovado ímpetu con la inclusión de la Península en el ámbito de la romanización.

\subsection{Los monumentos de Daimuz y Villajoyosa en el conjunto de los sepulcros turriformes romanos}

Los monumentos de Daimuz y Villajoyosa responden, en lo esencial, a la misma concepción monumental: una edícula cerrada de planta rectangular definida por un orden arquitectónico de pilastras corintias de esquina, con su entablamento correspondiente, que hay que suponer en ambos casos; la diferencia mayor se da en el tipo de basamento que ofrecen: un breve zócalo articulado sobre gradas en el de Villajoyosa y un zócalo prismático, simple y más alto, en el de Daimuz. El nicho arquitectónico de la fachada del segundo es otro detalle diferenciador importante, pero que no lo separa tipológicamente del sepulcro alicantino.
Cuando Laborde dibujó la torre sepulcral de Daimuz, se conservaba del nicho tan sólo el podio y las pilastras, pero no los capiteles ni el remate superior. Es lógico suponer que aquéllos fueron corintios, como los de las pilastras de las esquinas, $y$ para la cubrición cabe pensar en dos soluciones: un arquitrabe con frontón o un arco de medio punto, como se ofrece en las dos reconstrucciones de nuestra figura 29. Ambas soluciones son posibles (8), aunque la segunda, en forma de arco, parece más apropiada para estructuras huecas (mausoleo con templete períptero de Ghirza, monumento de los Julios de Glanum) y para otros que adoptan la repetida combinación de arcos apeados sobre pilastras y enmarcados por órdenes arquitrabados (monumento de Mas-de-Byran, en KOVACSOVICS, 1983, fig. 30,1), pero es también la solución adoptada en los relieves del podium de un monumento de Aquileia (ídem, lám. 6,1) o en el cuerpo superior de la propia Torre de los Escipiones, aunque en este caso no existan las pilastras que debían constituir el marco exterior (HAUSCHILD, MARINER, NIEMEYER, 1966, figs. 5 y 12). La primera solución, con arquitrabe y frontón, es también posible, por razones compositivas y sobre todo por la autonomía estructural del nicho respecto de la fachada en la que se integra (recuérdese la falsa puerta de la Tumba de Terón), como queda de manifiesto en la posesión de podio propio. En el interior del nicho debió figurar la representación de la Baebia Quieta a que se alude en la inscripción.

Otra cuestión es determinar si, como parecen sugerir algunos monumentos que más adelante se relacionarán, nuestros edificios pudieron haber tenido otro cuerpo superior con decoración arquitectónica. En principio, ninguno de los restos arqueológicos conservados o conocidos apoyan esta posibilidad, y las dimensiones de las torres, contando con que ambas culminaran en un piramidium, son ya bastante notables. Es cierto que la mayor parte de estos monumentos constan de tres cuerpos: zócalo, primer cuerpo más o menos decorado arquitectónicamente y piso alto principal, en el que se concentran los elementos arquitectónicos y escultóricos, además del remate correspondiente. En

(8) Existe una reconstrucción anterior de este edificio, obra de F. Pons (1973, reproducido por Aparicio, 1983, 333), cuya diferencia con la propuesta por nosotros estriba en que en aquélla las pilastras interiores se prolongan hasta el arquitrabe y en que el monumento se corona con almenas. 
nuestras torres, y aun a riesgo de forzar un tanto la realidad, podrían verse, comprimidos, los tres cuerpos característicos. En la de Villajoyosa (fig. 30) se observa que sobre el podio escalonado y como transición al cuerpo principal existe un zócalo bajo y articulado que no se confunde con las gradas del soporte inferior y que se individualiza con respecto al piso superior por la moldura que lo corona en todo su perímetro. En el de Daimuz, por el contrario, sobre una baja plataforma inferior se alzaría el podio y, sobre él, el cuerpo principal. Sin embargo, tanto en uno como en otro caso, esta diferenciación puede resultar algo forzada, y los monumentos parecen estar formados en realidad por sólo dos cuerpos: uno inferior, subdividido de una u otra manera, y otro superior, además del remate en forma de pirámide.

Las semejanzas entre los monumentos de Daimuz y Villajoyosa son tales que cabe atribuirlas a un mismo taller o, en todo caso, a arquitectos pertenecientes a una escuela común. Como se ha señalado, la diferencia más acusada reside en la composición del basamento: el de Villajoyosa se singulariza por añadir al podio y al cuerpo principal una grada muy desarrollada, elemento no muy frecuente en los monumenos de este tipo y posible testimonio de vinculaciones, como más adelante veremos, con otras áreas del Imperio. La torre de Daimuz, por último, se asienta sobre una plataforma más ancha, correspondiente a la recia cimentación que debía quedar en origen visible tan sólo por la cara superior de los sillares, como ocurre con otros monumentos de la misma familia.

La ubicación de los monumentos de Daimuz y Villajoyosa en el conjunto de los sepulcros turriformes romanos puede precisarse algo más atendiendo a tres aspectos básicos: la disposición exterior de los elementos arquitectónicos, la existencia de cámara interior y el tipo de cubierta posiblemente utilizado.

\subsubsection{Disposición exterior}

La fórmula esencial de los monumentos de Daimuz y Villajoyosa -edícula cerrada sobre zócalo prismático- es muy común en todo el Imperio. El primero de ellos se atiene estrictamente a las características básicas de tipo, en tanto en el segundo la inexistencia de edícula y la presencia de una grada escalonada muy desarrollada constituyen elementos claramente diferenciadores.
La mayor parte de los monumentos «de edícula» carecen de podio escalonado, tanto los de edícula propiamente dichos, tipológicamente bastante alejados de los nuestros (mausoleos de Asfionius Rufus en Sarsinia, L. Poblicius en Colonia, Calvius Turpius en Lyon - si es que realmente éste era de edícula abierta-, Pompeius Magnus en Albano, Mas-de-Byran, Lamazière y Saint Arailles; cf. KOVACSOVICS, 1983, 132, fig. 30), como los de edícula cerrada (tumbas de Terón en Agrigento, Poblicius Bibulus y Vergilius Eurysaces en Roma, monumentos hispanos como la tumba de Vilablareix o el grupo occidental de sepulcros turriformes (cf. KOVACSOVICS, 1983, 77 ss.; SANMARTÍ, 1984, 124 ss.; JIMÉNEZ, 1975, 869 ss.). No obstante, algunos monumentos, tanto de uno como de otro tipo, pueden alzarse sobre un podium escalonado que o bien es muy bajo - como ocurre con los tholoi de Aquileia y St. Remy, con la tumba de Cartilius Popicola en Ostia (GISMONDI, 1958, 170 ss.; figs. 71 ss.) o con las de C. Spectatus Priscianus y los Secundiani en Sempeter (GABELMANN, 1979, figs. 41,2 y 44,4) - o bien poseen gradas que apenas sobresalen unas de otras, como puede verse en los monumentos de las Guirnaldas de Pompeya, Bolonia (GABELMANN, 1979, fig. 42, 3), Aulus Murcius Obulaccus en Sarsinia (AURIGEMMA, 1963, 76 ss., fig. 84), Igel en Tréveris (ZAHN, 1982, 20, fig. 18), etc. Entre todos ellos, el monumento de Daimuz se relaciona especialmente con aquellos que sobre una grada de uno o dos escalones, algo más ancha que el resto del edificio, presentan un podio prismático, como los edificios de los Julios en St. Remy, Asfionius Rufus en Sarsinia y, sobre todo, el de Salonius en Lyon (KAEHLER, 1934, 159, fig. 3b), aunque en estos dos últimos exista una moldura entre la grada inferior y el podio propiamente dicho.

Basamentos como el de Villajoyosa, de varios escalones bien distanciados son raros, por no decir inexistentes, en el ámbito europeo del Imperio, incluso si incluyéramos los otros sepulcros turriformes (monópteros, tumulares, etc.) que ahora hemos sustraído a nuestra atención (cf. KOVACSOVICS, 1983, passim). En otras áreas del Imperio, las gradas de este tipo son más abundantes, aunque en ocasiones su función estructural sea bastante distinta.

En el Oriente, los monumentos funerarios turriformes presentan en algunos casos podios escalonados (GALIKOWSKI, 1970, 100, n. ${ }^{\circ}$ 98; 

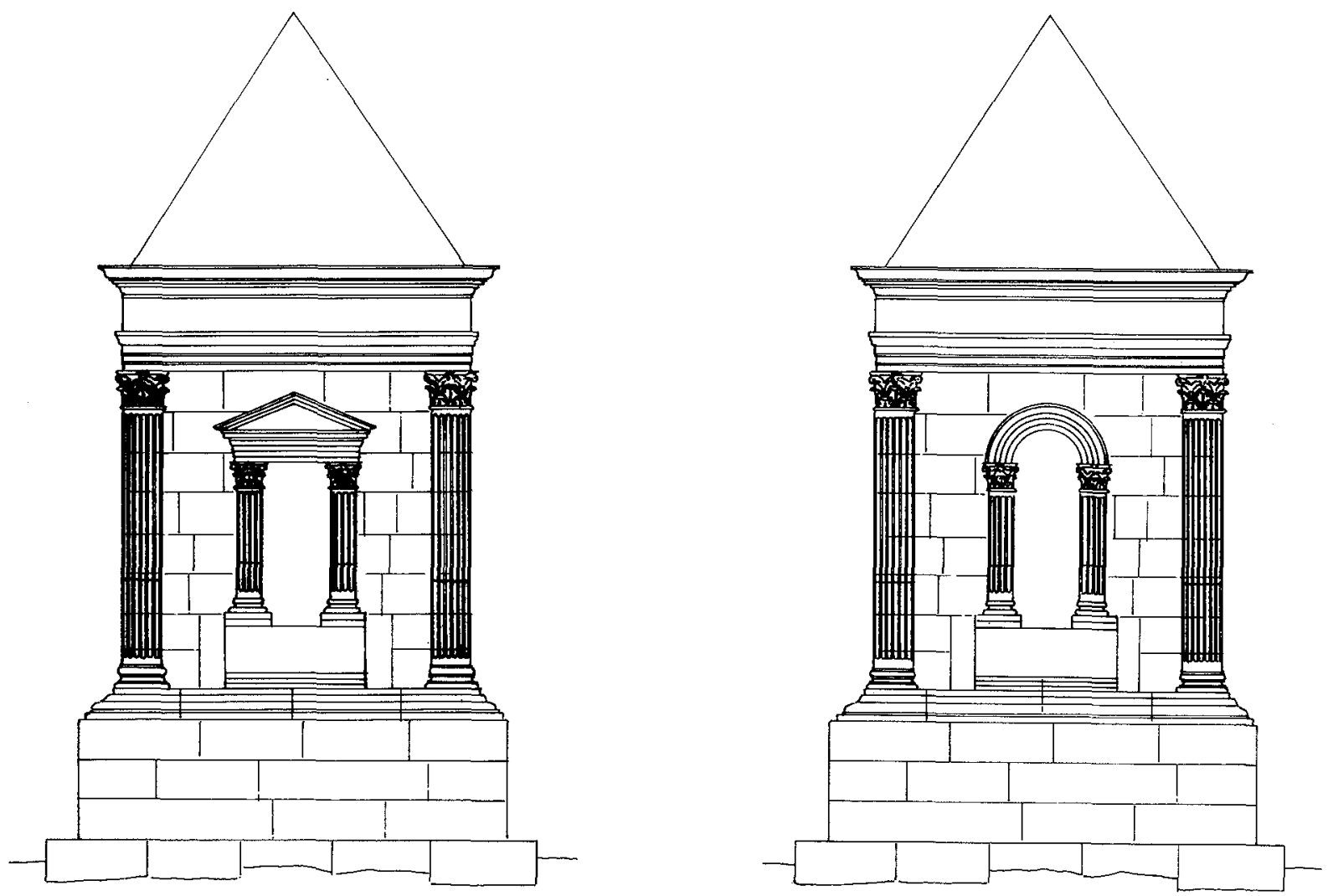

Fig. 29.-Proyectos de reconstrucción del monumento de Daimuz.

WILL, 1949, 94, n..$^{\circ 4}$ ), aunque en la inmensa mayoría de los casos o bien carecen de él o bien responden a un concepto muy diferente; $\mathrm{cf}$. las torres de Athenatan y de Jamblique (GALIKOWSKI, 1970, 54, n. ${ }^{\circ}$ 16; WILL, 1949, 95, lám. V, 2). El monumento cuyo podio más estrechamente recuerda al de Villajoyosa, el de Hermel (GALIKOWSKI, 1970, 100, n. ${ }^{\circ}$ 98; KRENCKER y ZSCHIETZSCHMANN, 1936, 162, figs. 232-233, WILL, 1951, 274, lám. xiii, 1), corresponde a un edificio bastante peculiar en el conjunto y datado en época helenística.

En el Norte de África, en cambio, disponemos de una larga serie de monumentos turriformes con podio escalonado que arranca de época púnica (POINSSOT y SALOMONSON, 1963, figs. 6 y 7; RAKOB, 1979, figs. 104, 106) y se continúa en la romana (RAKOB, 1979, 169, figs. 106 y 107; GSELL, 1901, 60, n. ${ }^{\circ}$ 2), aunque es de destacar que los mausoleos más tardíos lo reducen considerablemente hasta hacer desaparecer los escalones (RAKOB, 1979, 169, fig. 107; HAYNES, 1959, 157, fig. 21), Las reconstrucciones de monumentos funerarios ibéricos - tanto turriformes propiamente dichos como pilares-estela - que en los últimos años está realizando M. Almagro (1982, 198 ss.; 1983, 208 ss.) los muestran en la mayoría de los casos con podio escalonado $(1983,262, \mathrm{n}$. 178). Sería posible, por tanto, ver en el podium del monumento de Villajoyosa una perduración de estos podios ibéricos anteriores, aunque su estrecha relación con los monumentos norteafricanos contemporáneos resulta evidente. Es algo difícil de precisar todavía si esta relación es consecuencia de un origen norteafricano de este tipo de monumento, como en su día apuntaron Poinssot y Salomonson (1963, 79 ss.) o, más bien, consecuencia de un desarrollo paralelo a partir de modelos anteriores comunes (ALMAGRO, 1983, 214, n. 207). Lo evidente es que nuestro monumento guarda una mayor relación con los norteafricanos contemporáneos que con los de cualquier otra área del Imperio.

Otro elemento importante para la apariencia exterior del monumento lo constituye la decoración de las fachadas. La principal de la torre de 


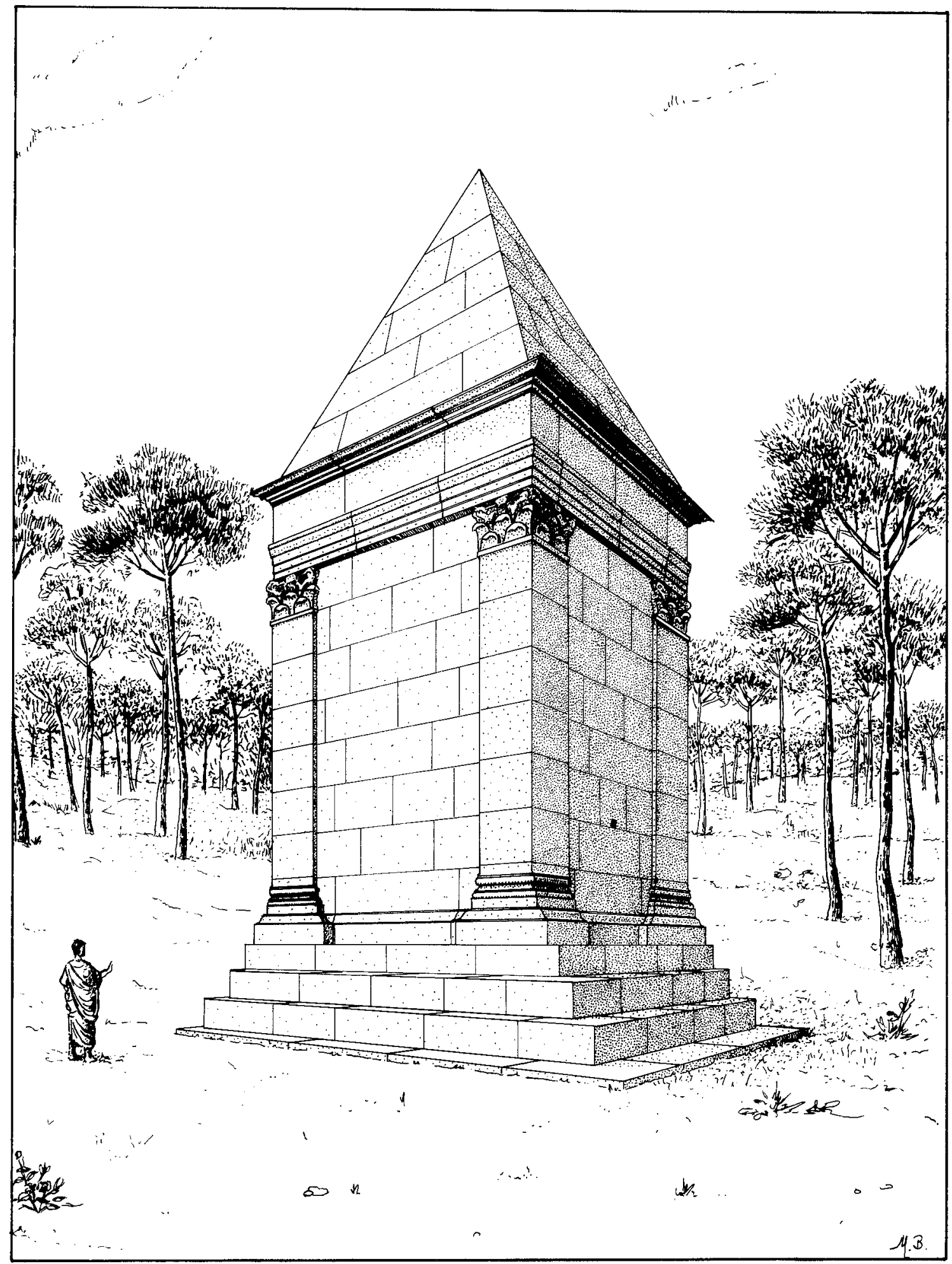

Fig. 30.-Proyecto de reconstrucción del monumento de Villajoyosa. 
Daimuz muestra un nicho sobre podio que obedece a una norma seguida genéricamente por los monumentos de esta clase: la de disponer de una suerte de nicho, puerta o arco simulado (si no se trata de un templete practicable), con valores decorativos y simbólicos, donde ubicar en ocasiones las imágenes de los difuntos, ya sean relivarias o de bulto redondo; el podio, por otra parte, proporcionaba el lugar idóneo para la inscripción dedicatoria. Este monumento encuentra perfecto acomodo entre los del tipo de «edícula cerrada», especialmente en la serie europea a que se adscriben edificios como los de Terón, Vergilius Eurysaces, Pompeius Magnus, Poblicius Bibulus, etc., datados entre el siglo II a. C. y la primera mitad del II d. C.

El monumento de Villajoyosa, en cambio, carece de todo complemento arquitectónico que no sea la estricta configuración de la edícula cerrada con pilastras de esquina, sobriedad que se extrema por la lisura de los fustes y la ausencia de detalles decorativos en los capiteles. Quizás se nos escape algún pormenor dada la situación actual del monumento, semicubierto por construcciones modernas, pero el examen de lo ahora visible, que es mucho, y los dibujos y descripciones de Lumiares y Laborde, no permiten añadir nada a lo ya dicho.

La mayor parte de los monumentos que, como el de Villajoyosa ofrecen una estructura tan sobria y cerrada, permiten comprobar que dicha estructura corresponde, en realidad, a los primeros pisos de monumentos en cuyo segundo cuerpo se abre la edícula correspondiente. Bástenos recordar la tumba de las Guirnaldas en Pompeya, las de Salonius y Calvius Turpius en Lyon, la de Poblicius en Colonia, las de Mas-de-Byran, Lamazière y St. Arailles, por citar sólo los ejemplos más conocidos. El monumento de Villajoyosa, por tanto, podría haber tenido un segundo cuerpo liso como los que acabamos de citar, pero de él no queda testimonio alguno. Por lo demás, y como hemos apuntado en otro lugar, es bastante probable que fuera de un solo piso, como parece evidente que lo fue el de Daimuz, tan próximo en lo geográfico y lo tipológico. Ambos monumentos quedarían así incluidos en un grupo de sepulcros turriformes hispánicos compuestos de basamento, piso principal y remate en pirámide $-u$ otras formas-, entre los que se cuentan la Torre de los Escipiones, la del Breny, la Torre Ciega de Cartagena y, tal vez, el mausoleo de Santa Eulalia en Almonaster (Huelva), entre otros.
La inscripción conmemorativa del monumento, de la que no se ha encontrado vestigio alguno, pudo estar en los sillares altos no conservados, como ocurre en las tumbas de Calvius Turpius de Lyon y de los Escipiones de Tarragona, o en el epistilio, según se hizo en el mausoleo de Fabara y otros. En este sentido, es preciso recordar la existencia de un sillar de grandes dimensiones con un espacio rectangular rehundido en su parte central que bien pudo haber alojado una placa de mármol o de otra clase de piedra con la correspondiente inscripción.

\subsubsection{Cubierta}

Las cubiertas más frecuentes en monumentos del tipo de los que estamos examinando son el frontón y la pirámide. El primero se encuentra en tumbas de todas las épocas, como la de las Guirnaldas (según la reconstrucción de KOCKEL, 1983, 134, fig. 25) y algunas, también pompeyanas, de la necrópolis de Puerta Nocera, en las tumbas de Sempeter y en algunas del Norte de África. Pero la cubierta más característica en los monumentos hasta ahora relacionados es, sin duda, la pirámide. Se ha propuesto que derive, o bien de la pirámide escalonada que cubría el Mausoleo de Halicarnaso y que se encuentra asimismo en otros monumentos orientales (monumento de Belevi, por ejemplo), o bien directamente de Egipto, donde hasta fines de la Antigüedad siguió utilizándose como cubierta de tumbas de particulares (OEHLMANN, 1953, 174 ss.; GAMER, 1982, 302; WAGNER, 1980, 90 ss. y 169 ss.).

El empleo de la pirámide puede deberse por una parte a su adecuación para cubrir edificios de planta cuadrada o rectangular, pero también sin duda a un contenido religioso y funerario derivado de su larga tradición en Egipto. Según Herman $(1964,125$ ss.), la pirámide como cubierta de tumba tendría un origen indudablemente egipcio, desde donde se difundiría muy pronto por Siria y Caria; desde aquí pasaría a África ya en época imperial, y posteriormente a Roma y Europa. Parece evidente que la difusión por el Oriente es muy antigua, pues ya en el siglo VII a. C. se detectan monumentos siriofenicios con este tipo de cubierta (WAGNER, 1980, 90 ss. y 160 ss.), pero la difusión por el Norte de África debió ser también anterior a la época imperial, pues no son pocos los monumentos púnicos que muestran ya una cubierta 
piramidal (RAKOB, 1963, 169); por una u otra vía debió llegar a Italia y, desde aquí, a Europa. No se debe olvidar, a este respecto, que el ejemplo más clásico de tumba en forma piramidal en la ciudad de Roma, el de C. Cestio, corresponde a alguien que ocupó cargos públicos en el propio Egipto.

La extensión de la pirámide por Europa se encuentra documentada -aunque casi siempre en reconstrucciones- en monumentos tan antiguos como los de Vergilius Eurysaces, con un remate piramidal muy bajo, o el de Salonius, en Lyon, aunque lo más probable es que la tuviera incluso el propio monumento de Terón. Pero el tipo de cubierta más característico de la Europa central será la pirámide de lados curvos que, aunque se encuentra atestiguada en monumentos orientales, como el mausoleo de Assar, en Comagene (CREMA, 1959, 256, fig. 287), ya en el siglo I a. C., donde abunda especialmente es en el Norte de Italia y Centro de Europa, desde época de Augusto hasta finales del siglo II d. C. Cubiertas de este tipo llevaron los monumentos de Sarsinia, Bolonia, Aquileia, Colonia y, en general, todos los del Rin, pero es prácticamente desconocida en el Oriente contemporáneo y en África.

El sepulcro turriforme de Tarragona, estudiado hace ya algunos años por Hauschild, Mariner y Niemeyer (1966, 170 ss.), fue reconstruido como terminado en una pirámide de lados rectos, aunque recientemente Gamer $(1982,312)$ ha expuesto la idea de que más bien debería ser de lados curvos, citando como paralelo una cubierta de este tipo, aún no publicada, encontrada en la provincia de Jaén. No obstante, de esta misma provincia se acaba de dar a conocer un nuevo mausoleo romano cuya cubierta, totalmente conservada, es una pirámide de lados rectos y ligeramente escalonados (GARCÍA PRIETO, 1985, 749 ss.). No tenemos constancia, pues, de cómo sería la cubierta de los monumentos de Daimuz y Villajoyosa, aunque, debido al tipo de edificio, parece evidente que debió ser una pirámide y, dada la relación con el Norte de África que muestran algunos de sus rasgos, parece lógico suponer que fuera de lados rectos, que es la más característicamente africana.

\subsubsection{La cámara interior}

Los monumentos de Daimuz y Villajoyosa poseen cámara interior, formada por el espacio que queda entre los muros. La de Daimuz (fig. 5), se- gún los dibujos de Laborde, estaba cubierta por una bóveda de sillería, apoyada en los lados mayores del edificio y con una altura que iba desde la parte inferior del capitel hasta el primer sillar del podio; el mismo autor indica que, en su parte inferior, se encontraba rodeada por un banco de piedra. No reproduce, en cambio, la cámara de la de Villajoyosa, posiblemente porque cuando la visitó se encontraba ya deformada por los pisos modernos de su interior. No obstante, hoy sabemos que estaba cubierta, como la de Daimuz, por una sólida bóveda de sillería, dispuesta de igual modo, que profundiza al menos dos metros por debajo del primer escalón del podio (figs. 9, 10 y 23). Ignoramos si el dibujo de Laborde, que coloca el suelo de la cámara de Daimuz a la altura del primer escalón del podio, es correcto, aunque, dado lo que ocurre en Villajoyosa, parece lógico suponer que lo que el viajero francés vio fue un piso - y un banco- moderno.

En cualquier caso, ambos monumentos contaban con sólidas bóvedas de sillería que por una parte cubrían un amplio espacio vertical sin compartimentar y por otra constituían un sólido apoyo para el piso o los pisos superiores. Ni en uno ni en otro caso hay huellas de que pudieran existir varias cámaras superpuestas, ya que no se conservan vestigios de la existencia de mechinales o resaltes como para sostener un piso interior. La cámara no contaba originalmente con ningún acceso desde el exterior, por lo que parece evidente que los monumentos debieron realizarse cuando ya se había efectuado el enterramiento a cuya protección estaba destinada; y explica también, en la torre de Villajoyosa, la existencia de un orificio en su lado norte, que debe interpretarse como el único punto de relación del interior de la tumba con el mundo exterior, a través del cual debían llegar al difunto las libaciones necesarias.

Relacionar el interior de nuestros monumentos con los de aquellos a los que hemos venido aludiendo a lo largo de las páginas anteriores es más difícil de lo que a primera vista podría pensarse, puesto que en muchas ocasiones las publicaciones no hacen referencia a la existencia o no de espacio interior. Según Matz (1928, 266 ss.), la mayor parte de los monumentos helenísticos de este tipo carecen de cámara funeraria, que tan sólo aparecería en los del Norte de África. Pero esta afirmación general sólo tiene un valor relativo, puesto que monumentos republicanos -igual podría decirse también 
tardohelenísticos - tan próximos como los de Terón en Agrigento y las Guirnaldas en Pompeya son radicalmente distintos en este aspecto: este último es macizo, en tanto el primero cuenta en su podium con una cámara sin comunicación con el exterior. Monumentos macizos son asimismo el de Hermel, del siglo I a. C., los de «friso dórico» que en realidad constituyen en no pocos casos el podium de un edificio turriforme (TORELLI, 1968, 32 ss.), varias de las tumbas de Pompeya y Ostia y una buena parte de los monumentos de edícula europeos, como los de Sarsinia, en algunos de los cuales se encontró la urna en una cavidad excavada en los cimientos. Otros muchos monumentos presentan, en cambio, un interior hueco pero no accesible; cuando la parte superior es en edícula abierta, la cámara se reduce por regla general al podium (caso de los monumentos de Fabara o Vilablareix entre los hispanos), pero cuando es total o parcialmente cerrada, la cámara puede estar compartimentada en tantos espacios como pisos tenga el monumento (casos de los sepulcros de L. Poblicius en Colonia o de la Torre del Breny en Barcelona), o ser única; en este caso, un solo espacio abierto unifica por el interior los diferentes pisos que el monumento muestra al exterior; es lo que ocurre en la Torre de los Escipiones, en el edificio de Miralpeix y en nuestras torres de Daimuz y Villajoyosa.

Este aislamiento del ambiente exterior es algo común a todas las tumbas europeas, ya que, tengan cámara o no, ésta es totalmente inaccesible desde el exterior, frente a los monumentos orientales, que - salvo excepciones como la ya apuntada de Hermel- se caracterizan por tener varias estancias interiores accesibles desde el exterior, y a los africanos de época romana, que en su mayor parte tienen también una cámara accesible desde el exterior. Las cámaras de las tumbas hispanas de este tipo carecían de comunicación con el exterior, y las puertas abiertas en muchos de ellos son de construcción moderna, como lo demuestra el que están hechas cortando uno (Villajoyosa) o varios sillares (Daimuz), incluso llegando a interrumpir las molduras de alguno de los cuerpos del edificio.

\section{CONCLUSIONES}

Con el estudio de los sepulcros turriformes de Daimuz y Villajoyosa hemos pretendido dar a conocer dos monumentos romanos prácticamente olvidados, pero de gran interés para la investigación arqueológica. Ambos se encuadran en el amplio conjunto de monumentos funerarios turriformes de época altoimperial y vienen a sumarse a los numerosos monumentos de este tipo existentes en España, que aún no han sido objeto del estudio de conjunto de que son merecedores. Las estrechas semejanzas entre ambos monumentos nos obligan a pensar en fechas de construcción bastante próximas que, a juzgar por algunos aspectos arquitectónicos y decorativos, podrían colocarse en el segundo tercio del siglo II d. C. No obstante, algunas diferencias, sobre todo en el basamento, permiten rastrear una mayor relación con prototipos norteafricanos para el monumento de Villajoyosa.

\section{BIBLIOGRAFÍA}

ABAD CASAL, L., 1985: «Arqueología romana del País Valenciano: panorama y perspectivas». Arqueología del País Valenciano: panorama y perspectivas. Alicante.

ALFOELDI, G., 1977: Los Baebii de Sagunto. Valencia.

ALMAGRO GORBEA, M., 1982: «El monumento de Alcoy. Aportación preliminar a la arquitectura funeraria ibérica». TP, 39.

- 1983: «Pozo Moro. Un monumento funerario ibérico orientalizante». $M M, 24$

ALMAGRO GORBEA, M., y JIMÉNEZ, J. L., 1982: «Metrología, modulación, trazado y reconstrucción del templo». El santuario de Juno en Gabii. Roma.

APARICIO, J.; GURREA, V. y CLIMENT, S., 1983: Carta arqueológica de La Safor. Gandía.

ASHBY, T., 1904: Sixteenth-Century Drawings of Roman Buildings attributed to Andreas Corner. PBSR, II.

AURIGEMMA, S., s. f.: L'arco de Marco Aurelio y L. Vero in Tripoli. I monumenti italiani, XIII. Roma.

BARRERA ANTÓN, J. L., 1984: Los capiteles romanos de Mérida. Monografías emeritenses, II. Badajoz.

BELTRÁN LLORIS, F., 1980: La epigrafia latina de Saguntum қ y su territorium. Valencia.

BEUTER, P. A., 1538: Crónica. Valencia.

BLANCO FREIJEIRO, A., 1976: El puente de Alcántara en su contexto histórico. Madrid.

BRUSIN, G., 1941: Nuovi monumenti sepolcrali di Aquileia. Venezia.

CEÁN BERMÚDEZ, J. A., 1832: Sumario de las antigüedades romanas que hay en España. Madrid.

CID PRIEGO, C., 1947-48: «El monumento conocido por "Torre de los Escipiones" en las cercanías de Tarragona». Ampurias, 9-10.

- 1949: «El sepulcro de torre mediterráneo y su relación con la tipología monumental». Ampurias, 11.

- 1950: «La torre del Breny, un sepulcro romano en las cercanias de Manresa». Ampurias, 12. 
CREMA, L., 1959: L'architettura romana. Enciclopedia Classica, XII. Torino.

DÍAZ MARTOS, A., 1960-61: «Los capiteles de orden corintio en Hispania». Ampurias, 22-23.

- 1985: Los capiteles corintios romanos en Hispania. Madrid.

ESCOLANO, G., 1610: Historia general de Valencia. Valencia.

FATAS, G., y MARTÍN BUENO, M. A., 1977: «Un mausoleo de época imperial en Sofuentes (Zaragoza)». $M M, 18$.

FERCHIOU, N., 1975: Architecture romaine de Tunisie. Túnez.

GABELMMAN, H., 1977: «Römische Grabbauten in Italien und den Nordprovinzen». Festschrift F. Brommer. Mainz.

- 1979: Römische Grabbauten der frühen Kaiserzeit. Stuttgart.

GAMER, G., 1982: «Sepulcrum Cnei et Publii Cornelii Scipionum. Das Monument bei Tarragona und andere Bauten in der Nachfolge des Maussolleions von Halikarnass»?. $M M, 23$.

GARCIA MERINO, C., 1977: “Un sepulcro turriforme en la Meseta Norte. El yacimiento arqueológico de Vildé (Soria)». BSEAA, XLIII.

GARCÍA PRIETO, J. A., y ORDIÑANA RODRÍGUEZ, M. V., 1985: «Un mausoleo romano en Alcalá la Real (Jaén)». XIII CNA. Zaragoza.

GAWLIKOVSKI, M., 1970: «Monuments funéraires de Palmyre. Warszawa.

GISMONDI, A., 1958: Le necropoli, Scavi di Ostia, III, $I$. Roma.

GSELL, ST. 1901: Les monuments antiques de l'Algérie, II. París.

GUTIÉRREZ BEHEMERID, M. A., 1982: «Sobre la sistematización del capitel corintio en la Península Ibérica». $B S E A A, 48$.

HAUSCHILD, Th.; MARINER, S. y NIEMEYER, H., 1966: " "Torre de los Escipiones". Ein römischer Grabturm bei Tarragona». $M M, 7$.

HAYNES, H., 1959: An archaeological and historical guide to the pre-Islamic Antiquities of Tripolitania. Tripoli.

HEILMEYER, W. D., 1970: Korintische Normalkapitelle. Studien zur Geschichte der römischen Architekturdekoration. Heidelberg.

HERMAN, A., 1964: «Porphyra und Pyramide. Zur Bedeutungsgeschichtlichen überlieferung eines Baugedankes». $J A C h r$.

HIRSCH, F., 1925: Die Entstehung der Säulenbasen des Altertums unter Berücksichtigung verwandter Kapitelle. Heidelberg.

JIMÉNEZ, A., 1975: «De Vitrubio a Vignola: autoridad de la tradición». Habis, 6.

- 1975: «El grupo occidental de sepulcros turriformes hispanos». Actas del XIII CNA. Zaragoza.

KÄHLER, H., 1934: «Die rheinischen Pfeilergrabmäler». $B j b, 139$.

KOCKEL, V., 1983: Die Grabbauten vor dem Herculaner Tor in Pompeji. Mainz.

KOVACSOVICS, W., 1983: Römische Grabdenkmäler. Bayern.

KRENCKER, D., y ZSCHIETZSCHMANN, D., 1936: Römische Tempel in Syrien. Berlín.
LABORDE, A. de, 1806: Voyage pittoresque et historique de l'Espagne. París.

LAMBOGLIA, N., 1961: Albenga. Albenga.

LANCKRONSKI, K. G., 1890: Städte Pamphiliens und Pisidiens. I. Wien.

LOSTAL PROUS, J., 1980: Arqueología del Aragón romano. Zaragoza.

LUMIARES, C. de, sf. Cf. VALCÁRCEL, A. de, sf.

LLOBREGAT, E. A., 1983: «Relectura del Ravennate: dos calzadas, una mansión inexistente y otros datos de geografía antigua del País Valenciano». Lucentum, II.

MANSUELLI, G., 1963: «Monumentum funerarium». $E A A, \mathrm{~V}$. MARCONI, P., 1929: Agrigento. Firenze.

MASSOW, W. von, 1932: Die Grabmäler von Neumagen. Berlín \& Leipzig.

MATZ, F., 1928: «Hellenistische und römische Grabbauten». Die Antike, 4.

NASH, E., 1967: Pictorial Dictionary of Ancient Rome. Roma.

OEHLMANN, F., 1953: «Aquileia una die Igeler Säule». Offerti il 7 ottobre 1953 a G. Brusin nel suo 70 compleanno. Aquileia.

PENSABENE, P., 1973: I capitelli, Scavi di Ostia, IX. Roma.

POINSSOT, C., y SALOMONSON, J. W., 1963: «Un monument punique inconnu: le masolée d'Henchir Djaouf d'apres les papiers inèdits du Comte C. Borgia». Oudheidkundige Medelingen, 44.

PONS MONCHO, F., 1973: «El sepulcro de Bebia Quieta». Revista de Feria y Fiestas de Gandía.

- 1977: «Camins romans a La Safor». Revista de Feria y Fiestas de Gandía. Gandía.

PRECHT, G., 1975: Das Grabmal des L. Poblicius. Köln.

PUIG I CADALFACH, J., 1934: L'arquitectura romana a Catalunya. Barcelona.

QUILICI, L., 1977: La via Appia da Roma a Bovillae. Roma.

RAKOB, F., 1979: «Numidische Königsarchitektur in Nordafrika», en HORN, H. G., y RUGER, Ch. B. Die Numider, Bonn.

RAMMANT-PEETERS, A., 1983: Les pyramidions ègyptiens du nouvel-empire. Leuven, 1983.

RIU, M., 1981: «La cerámica popular barcelonina del segle XIV. Aportació a l'estudi de les seves formes i marques». Acta Medievalia, 1.

ROMANELLI, P., 1970: Topografia e archeologia dell' Africa romana. Torino.

ROSETTO, P. C., 1973: Il sepolcro del fornaio Marco Virgilio Eurisace a Porta Maiore. Roma.

RODRÍGUEZ HIDALGO, J. M., 1979-80: «Anotaciones en torno a Basilippo. La Torre del Cincho». Habis, 10-11.

RUBIO ALIJA, J., 1959: «Españoles por los caminos del Imperio. Estudios epigráfico-onomásticos en torno a Reburrus y Reburrinus». Estudios de Historia de España, 29-30.

RUYT, D., 1983: Macellum. Louvain.

SANMARTI, J., 1984: «Edificis sepulcralis dels Països Catalans, Aragó i Murcia». Fonaments, 4.

STUCHI, S., 1975: Archittetura cirenaica. Roma.

TORELLI, M., 1968: «Monumenti funerari romani con fregio dorico». Dialoghi di Archeologia, 2. 
VALCÁRCEL, A. de, sf.: Inscripciones y Antigüedades del Reyno de Valencia. Memorias de la Real Academia de la Historia. Madrid.

WAGNER, P., 1980: Die ägyptische Einfluss auf die phönizische Architektur. Bonn.

WEGNER, M., 1966: Schmuckbasen des antiken Roms. Münster.
WIEGAND, Th. (ed.), 1932: Palmyra. Berlín.

WILL, E., 1949: «La tour funéraire de Palmyre». Syria, 26.

- 1951: «Monuments funéraires syriens en dehors de la Syrie». Syria, 28.

ZAHN, E., 1982: Die Igeler Säule in Igel bei Trier. Trier. 